\title{
Wytyczne EAACI/GA²LEN/EDF/WAO dotyczące definicji, klasyfikacji, diagnostyki i leczenia pokrzywki
}

\author{
T. Zuberbier ${ }^{\mathbb{1}}$, W. Aberer ${ }^{2}$, R. Asero ${ }^{3}{ }^{\mathbb{D}}$, A. H. Abdul Latiff ${ }^{4}$, D. Baker ${ }^{5}$, B. Ballmer-Weber ${ }^{6}$, \\ J. A. Bernstein ${ }^{7 \mathbb{D}}$, C. Bindslev-Jensen ${ }^{8}$, Z. Brzoza ${ }^{9}{ }^{\mathbb{D}}$, R. Buense Bedrikow ${ }^{10}$, G. W. Canonica ${ }^{11}$, \\ M. K. Church ${ }^{1}$, T. Craig ${ }^{12}$, I. V. Danilycheva ${ }^{13}$, C. Dressler ${ }^{14}$, L. F. Ensina ${ }^{15}$, A. Giménez-Arnau ${ }^{16}$, \\ K. Godse ${ }^{17}$, M. Gonçalo ${ }^{18}$, C. Grattan ${ }^{19}$, J. Hebert ${ }^{20}$, M. Hide ${ }^{21}$, A. Kaplan ${ }^{22}$, A. Kapp ${ }^{23}$, \\ C. H. Katelaris ${ }^{24}$, E. Kocatürk ${ }^{25}$, K. Kulthanan ${ }^{26}$, D. Larenas-Linnemann ${ }^{27}{ }^{(\mathbb{D}}$, T. A. Leslie ${ }^{28}$, \\ M. Magerl' ${ }^{1}$, P. Mathelier-Fusade ${ }^{29}$, R. Y. Meshkova ${ }^{30}$, M. Metz ${ }^{1}$, A. Nast ${ }^{14}$, E. Nettis ${ }^{31}$, \\ H. Oude-Elberink ${ }^{32}$, S. Rosumeck ${ }^{14}$, S. S. Saini ${ }^{33}$, M. Sánchez-Borges ${ }^{34}$, P. Schmid-Grendelmeier ${ }^{6}$, \\ P. Staubach ${ }^{35}$, G. Sussman ${ }^{36}$, E. Toubi ${ }^{37}$, G. A. Vena ${ }^{38}$, C. Vestergaard ${ }^{39}$, B. Wedi ${ }^{23}$, R. N. Werner ${ }^{14}$, \\ Z. Zhao ${ }^{40}$, M. Maurer'. Zaakceptowane przez następujące towarzystwa naukowe: AAAAl, AAD, \\ AAIITO, ACAAI, AEDV, APAAACI, ASBAI, ASCIA, BAD, BSACI, CDA, CMICA, CSACI, DDG, DDS, \\ DGAKI, DSA, DST, EAACI, EIAS, EDF, EMBRN, ESCD, GA²LEN, IAACI, IADVL, JDA, NVvA, MSAI, \\ ÖGDV, PSA, RAACI, SBD, SFD, SGAI, SGDV, SIAAIC, SIDeMaST, SPDV, TSD, UNBB, UNEV i WAO*
}

'Charité Universitätsmedizin Berlin, corporate member of Freie Universität Berlin, Humboldt-Universität zu Berlin, and Berlin Institute of Health, Department of Dermatology and Allergy, Allergy-Centre-Charité, Berlin, Niemcy

2Department of Dermatology, Medical University of Graz, Graz, Austria

${ }^{3}$ Department of Allergology, Clinica San Carlo, Paderno Dugnano, MI, Włochy

${ }^{4}$ Allergy\&Immunology Centre, Pantai Hospital Kuala Lumpur, Kuala Lumpur, Malezja

${ }^{5}$ Baker Allergy Asthma and Dermatology Clinic, Portland, OR, USA

${ }^{6}$ Allergy Unit, Department of Dermatology, University Hospital, Zürich, Szwajcaria

7 University of Cincinnati Physicians Immunology Research Center, Cincinnati, OH, USA

${ }^{8}$ Department of Dermatology and Allergy Centre, Odense University Hospital and University of Southern Denmark, Odense, Dania

${ }^{9}$ Klinika Chorób Wewnętrznych, Alergologii i Immunologii Klinicznej w Katowicach, Śląski Uniwersytet Medyczny, Katowice, Polska

${ }^{10}$ Santa Casa de Sao Paulo School of Medical Sciences, Sao Paulo, Brazylia

"Personalized Medicine Asthma and Allergy Clinic-Humanitas University\&Research Hospital, Mediolan, Włochy

${ }^{12}$ Department of Medicine and Pediatrics, Penn State University, Hershey Medical Center, Hershey, PA, USA

${ }^{13}$ National Research Center Institute of Immunology Federal Medical-Biological Agency of Russia, Moskwa, Rosja

${ }^{14}$ Charité Universitätsmedizin Berlin, corporate member of Freie Universität Berlin, Humboldt-Universität zu

Berlin, and Berlin Institute of Health, Division of Evidence Based Medicine, Department of Dermatology, Berlin, Niemcy

${ }^{15}$ Federal University of Sao Paulo, Sao Paulo, Brazylia

${ }^{16} \mathrm{Hospital}$ del Mar, IMIM, Universitat Autònoma Barcelona, Barcelona, Hiszpania

${ }^{17}$ Department of Dermatology, Dr. D. Y. Patil Medical College \& Hospital, Nerul, Navi Mumbai, Indie

${ }^{18}$ Clinic of Dermatology, Faculty of Medicine and University Hospital, Coimbra, Portugalia

${ }^{19}$ St John's' Institute of Dermatology, Guy's' and St. Thomas' Hospital, NHS Foundation Trust, Londyn, Wielka Brytania 
${ }^{20}$ Service d'allergie, Centre Hospitalier Université Laval/Centre Hospitalier Universitaire de Québec, Québec, QC, Kanada

${ }^{21}$ Department of Dermatology, Institute of Biomedical and Health Sciences, Hiroshima University, Hiroshima, Japonia

${ }^{22}$ Department of Medicine, Division of Pulmonary and Critical Care Medicine, Allergy and Clinical Immunology, Medical University of South Carolina, Charleston, SC, USA

${ }^{23}$ Department of Dermatology and Allergy, Hannover Medical School, Hannover, Niemcy

${ }^{24}$ Campbelltown Hospital and Western Sydney University, Sydney, Australia

${ }^{25}$ Department of Dermatology, Okmeydani Training and Research Hospital, Stambuł, Turcja

${ }^{26}$ Department of Dermatology, Faculty of Medicine Siriraj Hospital, Mahidol University, Bangkok, Tajlandia

${ }^{27}$ Hospital Médica Sur, Mexico City, Meksyk

${ }^{28}$ Royal Free Hospital, Londyn, Wielka Brytania

${ }^{29}$ Department of Dermatology and Allergy, University Hospital of Tenon, Paryż, Francja

${ }^{30}$ Department of Clinical Immunology and Allergy, Smolensk State Medical University, Smoleńsk, Rosja

${ }^{31}$ Scuola e Cattedra di Allergologia e Immunologia Clinica, Dipartimento dell'Emergenza e dei Trapianti d'Organo, Università di Bari, Bari, Włochy

${ }^{32}$ University of Groningen, Groningen, Holandia

${ }^{33}$ Johns Hopkins Asthma and Allergy Center, Baltimore, MD, USA

${ }^{34}$ Allergy and Clinical Immunology Department, Centro Médico-Docente La Trinidad, Caracas, Wenezuela

${ }^{35}$ Department of Dermatology, University Medical Center Mainz, Mainz, Niemcy

${ }^{36}$ Division of Allergy and Clinical Immunology, University of Toronto, Toronto, ON, Kanada

${ }^{37}$ Bnai-Zion Medical Center, Faculty of Medicine, Technion, Haifa, Izrael

${ }^{38}$ Dermatology and Venereology Private Practice, Bari and Barletta, Włochy

${ }^{39}$ Department of Dermatology and Venereology, Aarhus University Hospital, Aarhus, Dania

${ }^{40}$ Department of Dermatology and Venereology, Peking University, First Hospital, Beijing, Chiny

Allergy 2018; 73: 1393-1414 wileyonlinelibrary.com/journal/all

@2018 EAACI and John Wiley and Sons A/S. Opublikowane przez John Wiley and Sons Ltd.
Zaakceptowano: 18 grudnia 2017

DOI: $10.1111 /$ all.13397

Metody i podsumowanie przedstawiono w Dressler et al. Executive summary of the methods report for'The EAACI/GALEN/EDF/WAO Guideline for the Definition, Classification, Diagnosis and Management of Urticaria. The 2017 Revision and Update'. https://www.ncbi.nlm.nih.gov/ pubmed/29336489 Allergy. 2018 May;73(5):1145-1146. https://doi.org/10.1111/all.13414.

Skróty: AAS - skala aktywności obrzęku naczynioruchowego, ACE - enzym konwertujący angiotensynę, AE-QoL - kwestionariusz oceny jakości życia u pacjentów z obrzękiem naczynioruchowym, AGREE - narzędzie do oceny wytycznych (appraisal of guidelines research and evaluation), AOSD - choroba Stilla u dorosłych, ARIA - alergiczny nieżyt błony śluzowej nosa i jego wpływ na astmę (allergic rhinitis and its impact on asthma), ASST - test skórny z surowicą autologiczną, BAT - test aktywacji bazofilów, CAPS - okresowe zespoły zależne od kriopiryny, CIndU - pokrzywka przewlekła indukowalna, CSU - pokrzywka przewlekła spontaniczna, CU - pokrzywka przewlekła, CU-Q2oL-kwestionariusz oceny jakości życia u pacjentów z przewlekłą pokrzywką, CYP - cytochrom P, EAACl - European Academy of Allergology and Clinical Immunology, EDF - European Dermatology Forum, EtD - evidence-to-decisions, FCAS - rodzinny zespół autozapalny związany z oziębieniem, GA²LEN - Global Asthma and Allergy European Network, GDT - narzędzie do opracowywania wytycznych, GRADE - Grading of Recommendations Assessment - Development and Evaluation, HAE - wrodzony obrzęk naczynioruchowy, HIDS - zespół hiper-lgD, IVIG (także IGIV) - dożylne immunoglobuliny, MWS - zespół Muckle'a-Wellsa, NLPZ - niesteroidowe leki przeciwzapalne, NOMID - wielonarządowa choroba zapalna o początku w okresie noworodkowym, OUN - ośrodkowy układ nerwowy, PAF - czynnik aktywujący płytki krwi, PET - pozytonowa tomografia emisyjna, PICO - technika stosowana w medycynie opartej na dowodach - akronim pacjent/problem/populacja - interwencja - porównanie/kontrola/ komparator - wyniki (patient/problem/population - intervention - comparison/control/comparator - outcome), REM - szybkie ruchy gałek ocznych, sgAH - leki przeciwhistaminowe drugiej generacji, sJIA - młodzieńcze idiopatyczne zapalenie stawów o uogólnionym początku, TRAPS - zespół nawracających gorączek związany z receptorem dla TNF (czynnika martwicy nowotworów), UAS - skala aktywności pokrzywki, UCT - test kontroli pokrzywki, UEMS - European Union of Medical Specialists, UV - ultrafiolet, WAO - World Allergy Organization, WHO - World Health Organization.

*Towarzystwa naukowe akceptujące wytyczne oraz ograniczenia dotyczące akceptacji (AAAAl) przedstawiono w części Podziękowania.

Uwaga: Z uwagi na uniwersalność wytycznych nie zawierają one uwag dotyczących rejestracji wymienionych leków stosowanych w leczeniu chorych z pokrzywką. Lekarze leczący są zobowiązani do stosowania się do lokalnych regulacji obwiązujących w danym kraju.

[Poprawki wprowadzono 27 listopada 2018 r. po publikacji pierwszej wersji elektronicznej: Ryc. 1 zawierała wcześniej błędy i w przedstawionej wersji została poprawiona.] 


\section{STRESZCZENIE}

Przy użyciu metod zalecanych przez Cochrane i grupę roboczą Grading of Recommendations Assessment, Development and Evaluation (GRADE) opracowano wytyczne oparte na dowodach naukowych i konsensusie. Konferencja odbyła się 1 grudnia 2016 roku. Była wspólną inicjatywą Dermatology Section of the European Academy of Allergology and Clinical Immunology (EAACI), europejskiej sieci doskonałości (EU-founded network of excellence), Global Allergy and Asthma European Network (GA $\left.{ }^{2} \mathrm{LEN}\right)$, European Dermatology Forum (EDF) oraz World Allergy Organization (WAO); uczestniczyło w niej 48 delegatów z 42 krajowych i międzynarodowych towarzystw naukowych. Przedstawione wytyczne zostały uznane i zaakceptowane przez European Union of Medical Specialists (UEMS). Pokrzywka jest często występującą chorobą, będącą efektem pobudzenia komórek tucznych i objawiającą się występowaniem bąbli i/lub obrzękiem naczynioruchowym. Zachorowalność na pokrzywkę w ciągu całego życia wynosi około 20\%. Przewlekła pokrzywka spontaniczna oraz inne przewlekłe postaci ograniczają możliwość funkcjonowania chorego, pogarszają jakość życia i wpływają na codzienne aktywności związane z pracą i nauką. Przedstawione wytyczne obejmują definicję i klasyfikację pokrzywki z uwzględnieniem ostatnich postępów w określaniu przyczyn, czynników wywołujących oraz patomechanizmu pokrzywki. Odnoszą się także do opartych na dowodach naukowych metod diagnostyki i leczenia różnych podtypów pokrzywki.

\section{SŁOWA KLUCZOWE}

obrzęk naczynioruchowy, konsensus, oparty na dowodach naukowych, pokrzywka, bąbel.

\section{ADRES DO KORESPONDENCJ}

Torsten Zuberbier, Department of Dermatology and Allergy, Allergie-Centrum Charité, Charité

Universitätsmedizin Berlin, Berlin, Germany

e-mail: torsten.zuberbier@charite.de

\section{WPROWADZENIE}

Przedstawione wytyczne oparte na dowodach naukowych i konsensusie opracowano przy użyciu metod zalecanych przez Cochrane i grupę roboczą Grading of Recommendations Assessment, Development and Evaluation (GRADE). Dyskusję oraz uzgadnianie poszczególnych zaleceń prowadzono w ramach ustrukturyzowanego procesu uzgodnieniowego. Konferencja uzgodnieniowa odbyła się 1 grudnia 2016 roku w Berlinie w Niemczech.

Jest to wspólna inicjatywa Dermatology Section of the European Academy of Allergology and Clinical Immunolo$g y$ (EAACI), europejskiej sieci doskonałości (EU-founded network of excellence), Global Allergy and Asthma European Network (GA $\left.{ }^{2} \mathrm{LEN}\right)$, European Dermatology Forum (EDF) oraz World Allergy Organization (WAO); każda z tych organizacji uczestniczyła w finansowaniu opracowania uaktualnionej i zrewidowanej wersji wytycznych EAACI/GA²LEN/EDF/WAO dotyczących postępowania u chorych z pokrzywką [1-4]. Przedsięwziecie nie było finansowane $\mathrm{z}$ innych źródeł.

Przedstawioną uaktualnioną i zrewidowaną wersję wytycznych opracowało 44 ekspertów zajmujących się pokrzywką z 25 krajów, będących delegatami krajowych i międzynarodowych towarzystw naukowych (tab. 1). Wszystkie wymienione towarzystwa naukowe zaakceptowały wytyczne oraz wspierały proces ich opracowania przez pokrycie kosztów podróży i uczestnictwa ich delegatów w konferencji uzgodnieniowej. W opracowaniu uaktualnionej i zrewidowanej wersji wytycznych uczestniczył też zespół metodologów kierowany przez Alexandra Nasta, ze współpracą uczestników konferencji uzgodnieniowej (patrz tab. 1).

Coraz większe zróżnicowanie i coraz większa liczba różnych podtypów pokrzywki jest odzwierciedlone, przynajmniej częściowo, przez coraz większą wiedzę dotyczącą przyczyn i czynników wywołujących pokrzywkę oraz molekularnych i komórkowych mechanizmów patogenetycznych pokrzywki. Celem wytycznych jest przedstawienie definicji i klasyfikacji pokrzywki, a przez to ułatwianie interpretacji rozbieżnych danych pochodzących $\mathrm{z}$ różnych ośrodków i regionów świata dotyczących przyczyn, czynników wywołujących, obciążenia dla chorych i społeczeństwa oraz reakcji na leczenie poszczególnych podtypów pokrzywki. Wytyczne przedstawiają też zalecenia dotyczące metod diagnostyki i leczenia najczęstszych podtypów pokrzywki. Wytyczne mają charakter globalny 
TABELA 1. Członkowie grupy opracowującej wytyczne

\begin{tabular}{|c|c|c|}
\hline Imię & Nazwisko & $\begin{array}{c}\text { Organizacja } \\
\text { delegująca/ } \\
\text { afiliacja }\end{array}$ \\
\hline Alexander & Nast & \multirow[b]{2}{*}{$\begin{array}{l}\text { Division of Evidence- } \\
\text { Based Medicine, } \\
\text { Department of } \\
\text { Dermatology and } \\
\text { Allergy, Charité- } \\
\text { Universitätsmedizin } \\
\text { Berlin; Berlin, } \\
\text { Niemcy } \\
\end{array}$} \\
\hline Corinna & Dressler & \\
\hline Stefanie & Rosumeck & \\
\hline Ricardo N. & Werner & \\
\hline Werner & Aberer & ÖGDV \\
\hline Amir Hamzah & Abdul Latiff & MSAI \\
\hline Riccardo & Asero & AAIITO \\
\hline Diane & Baker & $A A D$ \\
\hline Barbara & Ballmer-Weber & SGAI \\
\hline Jonathan A. & Bernstein & AAAAI \\
\hline Carsten & Bindslev-Jensen & DSA, EAACI \\
\hline Zenon & Brzoza & PSA \\
\hline Roberta & Buense Bedrikow & SBD \\
\hline Walter & Canonica & WAO, SIAAIC \\
\hline Martin & Church & GA²LEN \\
\hline Timothy & Craig & ACAAI \\
\hline Inna Vladimirovna & Danilycheva & $\mathrm{RAACl}$ \\
\hline Luis Felipe & Ensina & ASBAI \\
\hline Ana & Giménez-Arnau & EAACl, AEDV \\
\hline Kiran & Godse & IADVL \\
\hline Margarida & Gonçalo & SPDV \\
\hline Clive & Grattan & $\mathrm{BSACl}, \mathrm{EAACl}$ \\
\hline Jaques & Hebert & CSACl \\
\hline Michihiro & Hide & JDA \\
\hline Allen & Kaplan & WAO \\
\hline Alexander & Kapp & DDG \\
\hline
\end{tabular}

\begin{tabular}{|c|c|c|}
\hline Imię & Nazwisko & $\begin{array}{c}\text { Organizacja } \\
\text { delegująca/ } \\
\text { afiliacja }\end{array}$ \\
\hline Constance & Katelaris & ASCIA, APAAACI \\
\hline Emek & Kocaturk & TSD \\
\hline Kanokvalai & Kulthanan & $\begin{array}{c}\text { DST (dołączyła do } \\
\text { panelu ekspertów } \\
\text { w październiku } \\
2016 \text { r.) }\end{array}$ \\
\hline Desiree & $\begin{array}{l}\text { Larenas- } \\
\text {-Linnemann }\end{array}$ & CMICA \\
\hline Tabi Anika & Leslie & BAD \\
\hline Markus & Magerl & UNBB \\
\hline Pascale & Mathelier-Fusade & $\begin{array}{c}\text { SFD, GUS (Groupe } \\
\text { Urticarie de la } \\
\text { Société francaise } \\
\text { de dermatologie), } \\
\text { będąca jedną } \\
\text { z podgrup SFD }\end{array}$ \\
\hline Marcus & Maurer & EAACl \\
\hline Raisa Yakovlevna & Meshkova & $\mathrm{RAACl}$ \\
\hline Martin & Metz & EMBRN \\
\hline Hanneke & Oude-Elberink & NvvA \\
\hline Sarbjit & Saini & AAAAI, WAO \\
\hline Mario & Sánchez-Borges & WAO \\
\hline Peter & $\begin{array}{c}\text { Schmid- } \\
\text {-Grendelmeier }\end{array}$ & SSDV \\
\hline Petra & Staubach & UNEV \\
\hline Gordon & Sussman & CSACI \\
\hline Elias & Toubi & $\mathrm{IAACI}$ \\
\hline Gino Antonio & Vena & SIDeMaST \\
\hline Christian & Vestergaard & DDS \\
\hline Bettina & Wedi & DGAKI \\
\hline Zuotao & Zhao & CDA \\
\hline Torsten & Zuberbier & EDF, GA²LEN \\
\hline
\end{tabular}

i uwzględniają różnice dotyczące czynników przyczynowych ze strony pacjentów oraz systemów opieki medycznej i dostępu do diagnostyki i leczenia w poszczególnych krajach.

\section{METODY}

Szczegółowe informacje dotyczące metod zastosowanych do opracowania zrewidowanych i uaktualnionych wytycznych EAACI/GA²LEN/EDF/WAO dotyczących 
pokrzywki opublikowano w oddzielnym raporcie, obejmującym wszystkie tabele GRADE [5].

Podsumowując $-\mathrm{w}$ przedstawionych, uaktualnionych i zrewidowanych wytycznych zastosowano narzędzie do oceny wytycznych AGREE II (Appraisal of Guidelines Research and Evaluation) [6] oraz metody sugerowane przez grupę roboczą GRADE. Przegląd piśmiennictwa przeprowadzono metodą opisaną w podręczniku Cochrane Handbook for Systematic Reviews of Interventions [7].

Do udziału w opracowaniu wytycznych powołano ekspertów z 42 towarzystw naukowych. W pierwszym etapie eksperci wybierali oraz oceniali kluczowe pytania i odpowiednie wyniki przy użyciu narzędzia internetowego [8]. Łącznie 30 członków panelu ekspertów wybrało 23 kluczowe pytania.

Następnie opracowano protokół przeglądu piśmiennictwa, określający strategie przeszukania piśmiennictwa, pytania będące przedmiotem badań zgodnie z techniką stosowaną w medycynie opartej na dowodach PICO (patient/problem/population, intervention, comparison/ control/comparator, outcome), kryteria włączenia, wyniki wybrane przez ekspertów, ryzyko błędów w trakcie oceny oraz strategie przekształcenia, syntezy i oceny danych.

Przegląd systematyczny piśmiennictwa przeprowadzono 1 czerwca 2016 roku; obejmowal 8090 pozycji. Dwie niezależne osoby oceniały piśmiennictwo oraz wyciągnięte dane. Po 2 fazach skriningu określono, że 65 badań spełnia kryteria włączenia. W każdym możliwym przypadku obliczano parametry określające odpowiedź wraz z odpowiadającymi przedziałami ufności (confidence interval - CI) oraz wykonano metaanalizę przy użyciu Review Manager [9]. Jakość dowodów oceniano na podstawie GRADE (Grading of Recommendations Assessment, Development and Evaluation) przy użyciu narzędzia GRADEpro Guideline Development Tool (GDT) $[10,11]$. Ogólną ocenę jakości dowodów naukowych uzyskano na podstawie oceny każdego wyniku w odniesieniu do 5 kryteriów (mianowicie ryzyko błędu, niezgodność, pośredniość, nieścisłość i błędy związane z publikacją) (tab. 2). Parametry efektów, takich jak ryzyko względne (risk ratio - RR), wyrażają wielkość efektu, natomiast oceny jakości - stopień wiarygodności uzyskanych wyników.
Następnie opracowano zmodyfikowane ramy oceny wpływu dowodów naukowych na podejmowane decyzje (evidence-to-decisions - EtD), które mają na celu pomoc ekspertom w ocenie wielkości pożądanych i niepożądanych efektów, równowagi między nimi oraz przedstawiające ogólną ocenę jakości. Ocena dowodów naukowych obejmowała 31 ram oceny profili dowodów naukowych lub oceny wpływu dowodów naukowych na podejmowane decyzje. Przy użyciu standardowych sformułowań przygotowywano pierwszą wersję zalecenia dotyczącego każdego kluczowego pytania opartego na dowodach naukowych (tab. 3).

$\mathrm{W}$ trakcie rundy głosowań internetowych przed konferencją przedstawiono wszystkie tabele GRADE i ramy EtD oraz propozycje zaleceń i przeprowadzono głosowania. Spośród 41 zaproszonych ekspertów (panel ekspertów) 30 wypełniło ankietę [odsetek odpowiedzi (response rate - RR) 73\%]. Wyniki przedstawiano panelowi ekspertów lub wprowadzano do ram EtD. Wszystkie ramy EtD oraz propozycje zaleceń udostępniono uczestnikom panelu przed konferencją uzgodnieniową.

W trakcie konferencji przeprowadzono głosowanie nad wszystkimi zaleceniami $z$ udziałem ponad 250 uczestników; wszyscy uczestnicy głosowania złożyli wcześniej (i) deklarację, że są specjalistami opiekującymi się pacjentami z pokrzywką oraz (ii) deklarację konfliktu interesów. W celu uzyskania zgody odnośnie do poszczególnych zaleceń zastosowano technikę nominalnej grupy (nominal group technique - NGT) [12]. Przebieg konferencji uzgodnieniowej był ściśle ustrukturyzowany: prezentacja dowodów naukowych i proponowanej wersji zalecenia, otwarta dyskusja, wstępne głosowanie lub zebranie propozycji alternatywnych sformułowań oraz ostateczne głosowanie, jeśli było konieczne. Uczestnicy biorący udział w głosowaniu otrzymali po jednej karcie zielonej i czerwonej oraz jedną $\mathrm{z}$ nich podnosili w trakcie głosowania za lub przeciw sugerowanemu zaleceniu. Wyniki głosowania dokumentowano. Silny konsensus określano jako zgoda w $>90 \%$, natomiast zgodę w zakresie $70-89 \%$ określano jako konsensus. Wszystkie zalecenia przyjmowano przy poziomie zgody wynoszącym $75 \%$. Cały proces poddano wewnętrznemu i zewnętrznemu przeglądowi.

TABELA 2. Podsumowanie metody GRADE stosowanej do oceny jakości dowodów naukowych dotyczących każdego wyniku [167]

\begin{tabular}{|l|l|}
\hline Wysoka (++++) & Jesteśmy pewni, że efekt rzeczywisty znajduje się blisko efektu obliczonego \\
\hline Umiarkowana (+++) & $\begin{array}{l}\text { Jesteśmy umiarkowanie pewni, że obliczony efekt jest wiarygodny: efekt rzeczywisty może znajdować się } \\
\text { blisko efektu obliczonego, ale możliwe też, że znacznie się różi }\end{array}$ \\
\hline Niska (++) & $\begin{array}{l}\text { Wiarygodność obliczonego efektu jest ograniczona: efekt rzeczywisty może znacznie różnić się od efektu } \\
\text { obliczonego }\end{array}$ \\
\hline Bardzo niska (+) & $\begin{array}{l}\text { Wiarygodność obliczonego efektu jest niewielka: efekt rzeczywisty prawdopodobnie znacznie różni się od } \\
\text { efektu obliczonego }\end{array}$ \\
\hline
\end{tabular}


TABELA 3. Standaryzowane sformułowania i symbole stosowane do opracowania zaleceń

\begin{tabular}{|c|c|c|c|}
\hline Rodzaj zalecenia & Sformułowanie & Symbole & Znaczenie \\
\hline $\begin{array}{l}\text { Silne zalecenie } \\
\text { dotyczące interwencji }\end{array}$ & “Zalecamy...” & $\uparrow \uparrow$ & $\begin{array}{l}\text { Uważamy, że wszystkie lub prawie wszystkie poinformowane } \\
\text { osoby dokonałyby takiego wyboru. Lekarze leczący będą musieli } \\
\text { poświęcić mniej czasu na proces podejmowania decyzji i mogą } \\
\text { poświęcić ten czasu przełamywaniu barier dotyczących zastoso- } \\
\text { wania i dostosowania. W większości sytuacji klinicznych zalecenie } \\
\text { można przyjąć jako zasadę }\end{array}$ \\
\hline $\begin{array}{l}\text { Warunkowe zalecenie } \\
\text { dotyczące interwencji }\end{array}$ & "Sugerujemy..." & $\uparrow$ & $\begin{array}{l}\text { Uważamy, że większość poinformowanych osób dokonałyby } \\
\text { takiego wyboru, jednak istotna liczba nie wybrałaby tej opcji. } \\
\text { Lekarze i pracownicy opieki medycznej będą musieli poświęcić } \\
\text { więcej czasu na proces podejmowania wspólnej decyzji. Decydenci } \\
\text { będą musieli uwzględnić różne opinie, a podejmowanie decyzji } \\
\text { wymaga przeprowadzenia szerokiej debaty }\end{array}$ \\
\hline $\begin{array}{l}\text { Warunkowe zalecenie } \\
\text { dotyczące interwencji } \\
\text { lub porównania }\end{array}$ & $\begin{array}{l}\text { "Nie możemy zalecać } \\
\text { w odniesieniu do..." }\end{array}$ & 0 & $\begin{array}{l}\text { W chwili obecnej nie można z różnych powodów sformułować } \\
\text { zalecenia za lub przeciw interwencji (np. brak dostępnych danych, } \\
\text { sprzeczne wyniki) }\end{array}$ \\
\hline $\begin{array}{l}\text { Warunkowe zalecenie } \\
\text { przeciwko interwencji }\end{array}$ & $\begin{array}{l}\text { "Sugerujemy, aby nie } \\
\text { stosować..." }\end{array}$ & $\downarrow$ & $\begin{array}{l}\text { Uważamy, że większość poinformowanych osób nie dokonałoby } \\
\text { wyboru tej interwencji, jednak istotna liczba osób wybrałaby tę } \\
\text { opcję }\end{array}$ \\
\hline $\begin{array}{l}\text { Silne zalecenie } \\
\text { przeciwko interwencji }\end{array}$ & $\begin{array}{c}\text { "Zalecamy } \\
\text { nie stosować..." }\end{array}$ & $\downarrow \downarrow$ & $\begin{array}{l}\text { Uważamy, że wszystkie lub prawie wszystkie poinformowane } \\
\text { osoby nie wybrałoby tej interwencji. W większości sytuacji } \\
\text { klinicznych zalecenie można przyjąć jako zasadę }\end{array}$ \\
\hline
\end{tabular}

Wszystkie uzgodnione zalecenia oznaczono na szaro, wskazując też, czy są oparte na opinii ekspertów (uzyskanej w drodze konsensusu) lub dowodach naukowych i opinii ekspertów (na podstawie dowodów naukowych i konsensusu).

\section{DEFINICJA}

\subsection{DEFINICJA}

Pokrzywka jest stanem charakteryzującym się występowaniem bąbli lub obrzęku naczynioruchowego albo obydwu objawów. Pokrzywka wymaga różnicowania $\mathrm{z}$ innymi zaburzeniami przebiegającymi z obecnością bąbli, obrzęku naczynioruchowego lub obydwoma objawami, np. $z$ anafilaksją, zespołami autoimmunologicznymi, pokrzywkowym zapaleniem naczyń lub obrzękiem naczynioruchowym wywołanym bradykininą, w tym wrodzonym obrzękiem naczynioruchowym (hereditary angioedema - HAE).

\section{Definicja}

Pokrzywka jest stanem charakteryzującym się występowaniem bąbli lub obrzęku naczynioruchowego albo obydwu tych objawów.

(A) Bąble u pacjentów z pokrzywką wykazują trzy charakterystyczne cechy:
1) obecność obrzęku w części centralnej o różnej wielkości, prawie zawsze otoczonego strefą zaczerwienienia,

2) obecność świądu lub uczucia palenia,

3) charakter przejściowy, z powrotem skóry do prawidłowego wyglądu, zwykle w ciągu 30 minut do 24 godzin.

(B) Obrzęk naczynioruchowy u pacjentów z pokrzywką charakteryzuje się:

1) nagłym, wyraźnie rumieniowym lub w barwie skóry obrzękiem głębszych warstw skóry oraz tkanek podskórnych lub błon śluzowych,

2) w niektórych przypadkach obecnością bólu, a raczej nie swędzenia,

3) wolniejszym ustępowaniem niż w przypadku bąbli (do 72 godzin).

\subsection{KLASYFIKACJA POKRZYWKI NA PODSTAWIE CZASU JEJ TRWANIA ORAZ CZYNNIKÓW WYWOŁUJĄCYCH}

Spektrum objawów klinicznych poszczególnych podtypów pokrzywki jest bardzo zróżnicowane. Ponadto $\mathrm{u}$ jednego chorego można stwierdzić 2 lub więcej różnych postaci pokrzywki.

Ostrą spontaniczną pokrzywkę określa się jako spontaniczne występowanie bąbli, obrzęku naczynioruchowego lub obu tych objawów przez okres krótszy niż 6 tygodni. 


\begin{tabular}{|l|c|c|}
\hline \multicolumn{2}{|l|}{ Jak należy klasyfikować pokrzywkę? } \\
\hline Zalecamy, aby na podstawie czasu trwania & $\uparrow \uparrow$ & Konsensus \\
klasyfikować pokrzywkę jako ostrą & & $>90 \%$ \\
( $\leq 6$ tygodni) lub przewlekłą (> 6 tygodni). & & \\
Zalecamy, aby pokrzywkę klasyfikować jako & & \\
spontaniczną (bez określonych czynników & & \\
wywołujących) lub indukowalną (z obecno- & & \\
ścią określonych czynników wywołujących) & & \\
(w oparciu o konsensus) & & \\
\hline
\end{tabular}

W tabeli 4 przedstawiono klasyfikację podtypów przewlekłej pokrzywki (chronic urticaria - CU) opracowaną dla celów klinicznych. Klasyfikację tę zgodnie z konsensusem
(> 90\%) pozostawiono w takiej samej wersji jak w poprzedniej wersji wytycznych, natomiast pokrzywkowe zapalenie naczyń, plamisto-grudkowa mastocytoza skórna (cutaneous mastocytosis - CM) [dawniej określana jako pokrzywka barwnikowa (urticaria pigmentosa - UP)], zespoły autozapalne [np. okresowe zespoły zależne od kriopiryny (cryopyrin -associated periodic syndrome - CAPS) lub zespół Schnitzler], obrzęk naczynioruchowy wywołany mediatorami innymi niż komórek tucznych (np. obrzęk naczynioruchowy wywołany bradykininą) oraz inne choroby, takie jak zespoły, które mogą objawiać się występowaniem bąbli i/lub obrzęku naczynioruchowego, nie są uznawane za podtypy pokrzywki z uwagi na wyraźnie odmienne mechanizmy patofizjologiczne (tab. 5).

TABELA 4. Zalecana klasyfikacja przewlekłej pokrzywki

\begin{tabular}{|c|c|}
\hline \multicolumn{2}{|c|}{ Podtypy przewlekłej pokrzywki } \\
\hline Przewlekła pokrzywka spontaniczna (CSU) & Pokrzywka indukowalna \\
\hline $\begin{array}{l}\text { Spontaniczne pojawianie się bąbli, obrzęku naczynioruchowego } \\
\text { lub obydwu objawów przez > } 6 \text { tygodni pod wpływem znanych } \\
\text { lub nieznanych przyczyn }\end{array}$ & $\begin{array}{c}\text { Dermografizm objawowy } \\
\text { Pokrzywka z zimna } \\
\text { Opóźniona pokrzywka z ucisku } \\
\text { Pokrzywka słoneczna } \\
\text { Pokrzywka z ciepła } \\
\text { Obrzęk naczynioruchowy wibracyjny } \\
\text { Pokrzywka cholinergiczna } \\
\text { Pokrzywka kontaktowa } \\
\text { Pokrzywka akwageniczna }\end{array}$ \\
\hline
\end{tabular}

aNa przykład autoreaktywność, tzn. obecność autoprzeciwciał aktywujących komórki tuczne.

'ZZwana także urticaria factitia lub pokrzywką dermograficzną.

'Zwana także pokrzywką wskutek kontaktu z zimnem.

¿Zwana także pokrzywką z ucisku.

eZwana także pokrzywką wskutek kontaktu z ciepłem.

TABELA 5. Choroby związane zwyczajowo z pokrzywką oraz zespoły przebiegające z obecnością bąbli i/lub obrzęku

- Plamisto-grudkowa mastocytoza skórna (pokrzywka barwnikowa)

- Pokrzywkowe zapalenie naczyń

- Obrzęk naczynioruchowy wywołany bradykininą (np. HAE)

- Anafilaksja indukowana wysiłkiem

- Okresowe zespoły zależne od kriopiryny (CAPS; wysypka pokrzywkowa, nawracające epizody gorączki, bóle lub zapalenie stawów, zapalenie oka, zmęczenie i bóle głowy), obejmujące rodzinny autozapalny zespół reakcji na zimno (familial cold auto-inflammatory syndrome - FCAS), zespół Muckle'a-Wellsa (Muckle-Wells syndrome - MWS) lub wielonarządowa choroba zapalna o początku w okresie noworodkowym (neonatal-onset multisystem inflammatory diseases - NOMID)

- Zespół Schnitzler (nawracająca wysypka pokrzywkowa i gammapatia monoklonalna, nawracające epizody gorączki, bóle kości i mięśni, bóle lub zapalenie stawów oraz powiększenie węzłów chłonnych)

- Zespół Gleicha (epizodyczny obrzęk naczynioruchowy z eozynofilią)

- Zespół Wella (ziarniniakowe zapalenie skóry z eozynofilią lub eozynofilowym zapaleniem tkanki podskórnej)

- Pemfigoid (stan przedpęcherzycowy)

Wymienione choroby i zespoły są związane $\mathrm{z}$ pokrzywką (1) z uwagi na możliwość występowania bąbli, obrzęku naczynioruchowego lub obu tych objawów i/lub (2) zwyczajowo.

\begin{tabular}{|l|l|l|}
\hline $\begin{array}{l}\text { Czy należy utrzymać w obecnej wersji wytycznych } \\
\text { dotychczasową klasyfikację przewlekłej pokrzywki? }\end{array}$ \\
\hline $\begin{array}{l}\text { Zalecamy utrzymanie w obecnej wersji } \\
\text { wytycznych dotychczasowej klasyfikacji }\end{array}$ & $\uparrow$ & $\begin{array}{c}\text { Konsensus } \\
>90 \%\end{array}$ \\
$\begin{array}{l}\text { przewlekłej pokrzywki (w oparciu } \\
\text { o konsensus) }\end{array}$ & & \\
\hline
\end{tabular}




\subsection{ASPEKTY PATOFIZJOLOGICZNE}

Pokrzywka jest chorobą związaną z aktywnością komórek tucznych. Działanie histaminy oraz innych mediatorów, takich jak czynnik aktywujący płytki krwi (platelet-activating factor - PAF) i cytokiny uwalniane $\mathrm{z}$ aktywowanych komórek tucznych skóry, prowadzi do aktywacji nerwów czuciowych, rozszerzenia naczyń krwionośnych i wynaczynienia osocza, a także do rekrutacji komórek do zmian pokrzywkowych. Sygnały aktywujące komórki tuczne w przebiegu pokrzywki są związane $\mathrm{z}$ chorobą podstawową i mogą być $\mathrm{w}$ związku $\mathrm{z}$ tym bardzo heterogenne i zróżnicowane. Histologicznie bąble charakteryzują się obrzękiem górnych i środkowych warstw skóry, z poszerzeniem i zwiększeniem przepuszczalności żył pozawłośniczkowych i naczyń limfatycznych górnych warstw skóry, prowadzącym do przesięku surowicy do otaczających tkanek. W przebiegu obrzęku naczynioruchowego zachodzą podobne zmiany, głównie jednak w dolnych warstwach skóry i w tkance podskórnej. W skórze zajętej bąblami zawsze dochodzi do zwiększenia aktywności cząstek adhezyjnych w obrębie komórek śródbłonka, neuropeptydów i czynników wzrostu, mieszanych nacieków zapalnych okołonaczyniowych o zmiennym nasileniu, obejmujących neutrofile $\mathrm{z}$ obecnością lub bez eozynofilów, bazofilów, makrofagów i limfocytów T, ale bez martwicy ściany komórkowej, będącej charakterystycznym objawem pokrzywkowego zapalenia naczyń [13-17]. Skóra niezajęta bąblami w przebiegu przewlekłej pokrzywki spontanicznej (CSU) wykazuje zwiększenie aktywności cząstek adhezyjnych [18], nacieki eozynofilowe oraz zmianę ekspresji cytokin [19]. Niektórzy autorzy opisywali łagodne lub umiarkowane zwiększenie liczby komórek tucznych. Obserwowane zmiany podkreślają złożony charakter patogenezy pokrzywki, obejmujący wiele innych czynników poza uwalnianiem histaminy z komórek tucznych w skórze [20-22]. Niektóre $\mathrm{z}$ tych zmian stwierdza się też $\mathrm{w}$ wielu innych stanach zapalnych, dlatego nie są one charakterystyczne i nie wykazują wartości diagnostycznej. Konieczne jest poszukiwanie bardziej swoistych biomarkerów histologicznych dla różnych podtypów pokrzywki, umożliwiających odróżnienie pokrzywki od innych zaburzeń [23].

\subsection{OBCIĄŻENIE ZWIĄZANE Z CHOROBA}

Pokrzywka przewlekła wiąże się z istotnym obciążeniem dla pacjentów, ich rodzin oraz przyjaciół, ale także dla systemu opieki zdrowotnej i społeczeństwa. Zastosowanie narzędzi z grupy wyników relacjonowanych przez chorych (patient-reported outcome - PRO), takich jak skala aktywności pokrzywki (urticaria activity score - UAS), skala aktywności obrzęku naczynioruchowego (angioede- ma activity score - AAS), kwestionariusz jakości życia chorych na pokrzywkę przewlekłą (CU quality of life - CU-Q2oL), kwestionariusz jakości życia chorych z obrzękiem naczynioruchowym (angioedema quality of life - AE-QoL) oraz test kontroli pokrzywki (urticaria control test - UCT), w badaniach i praktyce klinicznej pomogło lepiej zdefiniować następstwa i wpływ CU na pacjentów [24]. Dostępne dane wskazują, że pokrzywka istotnie wpływa zarówno na obiektywne funkcjonowanie, jak i subiektywne samopoczucie chorych [25-27]. We wcześniejszym badaniu O'Donnell i wsp. wykazali, że oceny stanu zdrowia u chorych z CSU są porównywalne z wynikami odnotowanymi $\mathrm{u}$ chorych $\mathrm{z}$ chorobą wieńcową [28]. Ponadto zarówno stan zdrowia, jak i subiektywne zadowolenie u chorych na CSU są gorsze niż u zdrowych osób oraz chorych $\mathrm{z}$ alergią układu oddechowego [29]. CU wiąże się też z istotnymi kosztami ponoszonymi zarówno przez chorych, jak i społeczeństwo [30-32].

\section{ROZPOZNANIE POKRZYWKI}

\subsection{BADANIA DIAGNOSTYCZNE W OSTREJ POKRZYWCE}

Ostra pokrzywka ma zwykle charakter samoograniczający, dlatego najczęściej nie wymaga wykonywania badań diagnostycznych. Jedynym wyjątkiem jest podejrzenie ostrej pokrzywki wywołanej alergią pokarmową typu I u uczulonych chorych lub obecność innych czynników wywołujących, takich jak niesteroidowe leki przeciwzapalne (NLPZ). W tym przypadku wykonanie testów alergicznych oraz odpowiednia edukacja chorego może umożliwić uniknięcie ponownej ekspozycji na odpowiednie czynniki wywołujące.

\section{Czy u chorych z ostrą pokrzywką należy wykonywać rutynowe badania diagnostyczne?}

\begin{tabular}{|l|l|l}
\hline Zalecamy, aby nie wykonywać rutynowych & $\downarrow \downarrow$ & Konsensus
\end{tabular} badań diagnostycznych u chorych z ostrą $\quad>90 \%$

pokrzywką (w oparciu o konsensus)

\subsection{BADANIA DIAGNOSTYCZNE W CU}

Trzy najważniejsze cele wykonywania badań diagnostycznych u chorych na CSU obejmują: (i) przeprowadzenie diagnostyki różnicowej, (ii) ocenę aktywności i następstw choroby oraz jej kontroli, a także (iii) identyfikację czynników prowadzących do zaostrzenia lub, w uzasadnionych przypadkach, przyczyn leżących u podstawy obserwowanych zmian. Ad. (1) Bąble i obrzęk naczynioruchowy mogą też występować w przebiegu innych chorób. U chorych z obecnością samych bąbli, bez obrzęku naczynioruchowego należy wykluczyć pokrzywkowe zapalenie 
naczyń i choroby autozapalne, takie jak zespół Schnitzler lub okresowe zespoły zależne od kriopiryny (CAPS). $\mathrm{Z}$ drugiej jednak strony u chorych z nawracającym obrzękiem naczynioruchowym (ale bez obecności bąbli) w diagnostyce różnicowej należy uwzględnić obrzęk na- czynioruchowy mediowany bradykininą wywołany inhibitorem enzymu konwertującego angiotensynę (ACE) lub inne rodzaje obrzęku naczynioruchowego niezwiązanego z aktywnością komórek tucznych, takie jak HAE typu 1-3 (ryc. 1). Ad. (2) Początkowa ocena aktywności choroby

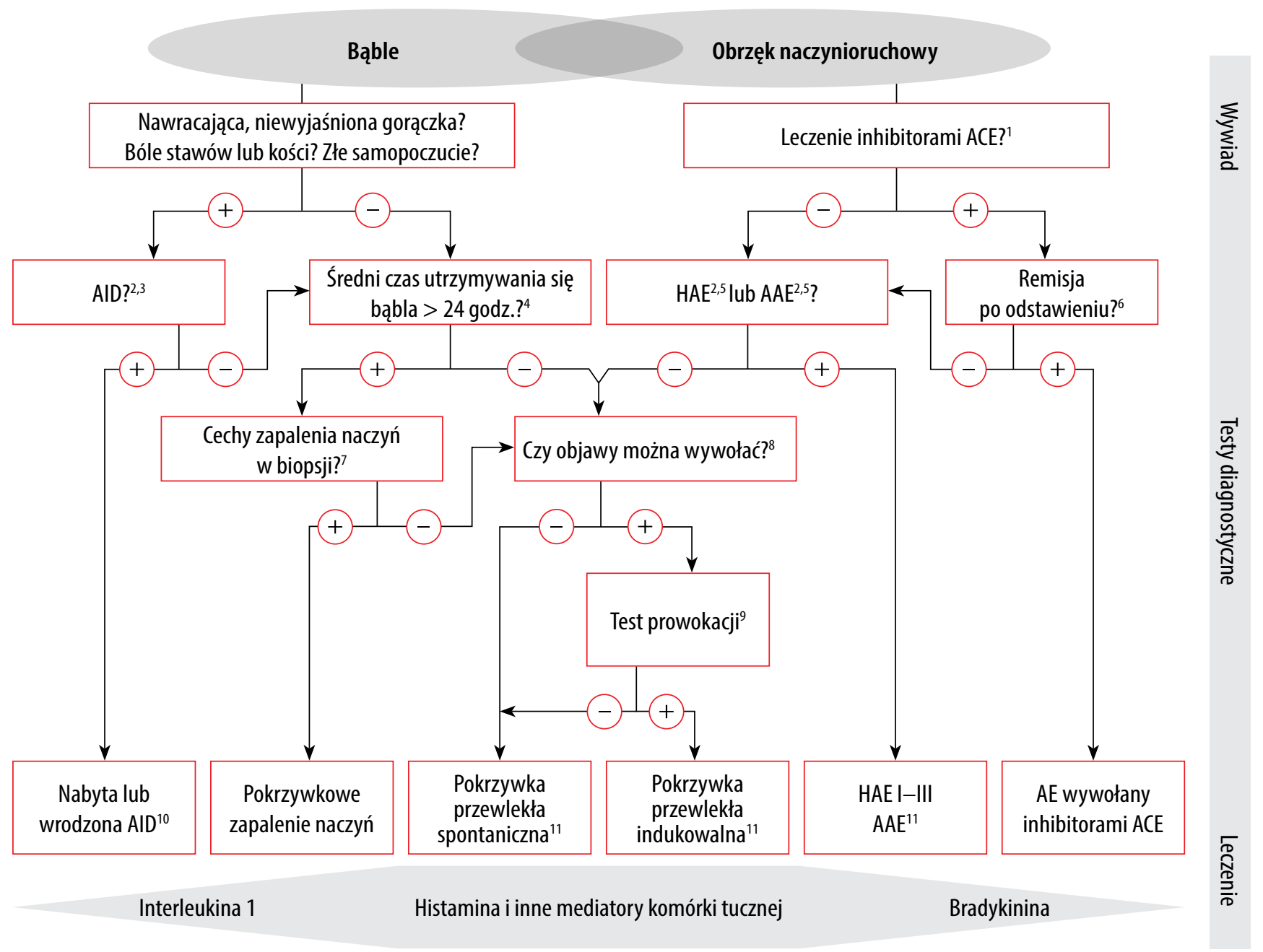

RYCINA 1. Zalecany algorytm postępowania diagnostycznego u chorych z przewlekłą pokrzywką. Algorytm diagnostyczny dla chorych z obecnością bąbli, obrzęku naczynioruchowego lub z obydwoma objawami. AAE - nabyty obrzęk naczynioruchowy wywołany niedoborem inhibitora C1, inhibitor ACE - inhibitor enzymu konwertującego angiotensynę, AE - obrzęk naczynioruchowy, AID - choroba autozapalna, HAE - wrodzony obrzęk naczynioruchowy, RAS - układ renina-angiotensyna

'Poza inhibitorami ACE również inne inhibitory reniny i sartany mogą wywołać obrzęk naczynioruchowy, choć dużo rzadziej. ${ }^{2}$ Należy zebrać szczegółowy wywiad rodzinny od chorego oraz uzyskać informacje dotyczące wieku, w którym wystąpiły pierwsze objawy choroby. ${ }^{3} \mathrm{~W}$ przypadku wyraźnych wskazań należy przeprowadzić badania w kierunku zwiększonego poziomu markerów zapalnych (białko C-reaktywne, odczyn Biernackiego), u dorosłych badanie w kierunku paraproteinemii, ocena w kierunku obecności nacieków bogatych w neutrofile w bioptatach skóry; wykonanie analizy mutacji genów w kierunku wrodzonych okresowych zespołów gorączkowych [np. okresowych zespołów zależnych od kriopiryny (CAPS)]. “Należy zadać pytanie choremu: „Jak długo utrzymywał się każdy bąbel?”. ' ${ }^{\text {Badanie }}$ w kierunku składowej układu dopełniacza C4, stężenie i aktywność C1-INH; w przypadku podejrzenia AAE badanie w kierunku obecności przeciwciał skierowanych przeciwko C1q i C1-INH; jeśli wyniki wcześniejszych badań nie są jednoznaczne, ale wywiad sugeruje obecność wrodzonego obrzęku naczynioruchowego, należy wykonać analizę mutacji genów. ${ }^{6} \mathrm{~W}$ przypadku braku remisji po 6 miesiącach od zakończenia podawania inhibitora ACE należy wykonać badanie w kierunku inhibitora $\mathrm{C}{ }^{\top} \mathrm{C} z y$ biopsja skóry zajętej zmianami wykazała uszkodzenie małych naczyń w warstwie brodawkowej i siateczkowej skóry i/lub okołonaczyniowe i śródmiąższowe złogi fibrynoidu sugerujące pokrzywkowe zapalenie skóry? ${ }^{8} \mathrm{Należy} \mathrm{zadać} \mathrm{pytanie} \mathrm{choremu:} \mathrm{„Czy}$ może Pan (Pani) spowodować pojawienie się bąbli? Czy może Pan (Pani) spowodować, aby bąble ustąpiły?" "U chorych z wywiadem sugerującym indukowalną pokrzywkę

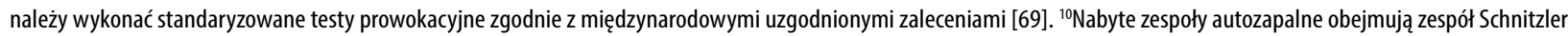
oraz młodzieńcze idiopatyczne zapalenie stawów o uogólnionym początku (sJIA) i chorobę Stilla u dorosłych (AOSD); wrodzone zespoły autozapalne obejmują okresowe CAPS, takie jak rodzinny zespół autozapalny związany z oziębieniem (FCAS), zespół Muckle-Wellsa (MWS) i wielonarządową chorobę zapalną o początku w okresie noworodkowym (NOMID), rzadziej zespół hiper-IgD (hyper-IgD syndrome - HIDS) i zespół nawracających gorączek związany z receptorem dla TNF- $\alpha$ (czynnika martwicy nowotworów) (tumour necrosis factor receptor alpha-associated periodic syndrome - TRAPS). ${ }^{11} \mathrm{~W}$ niektórych rzadkich przypadkach nawracający obrzęk naczynioruchowy nie jest efektem aktywności komórek tucznych ani bradykininy, a patomechanizm choroby nie jest znany. Niektórzy autorzy te rzadkie przypadki określają mianem „idiopatyczny obrzęk naczynioruchowy”. 
(UAS, AAS), jakości życia (CU-Q2oL, AE-QoL) i kontroli choroby (UCT) jest niezbędna do podejmowania decyzji terapeutycznych, daje lepszy wgląd w obciążenie chorego związane z chorobą oraz ułatwia, poprawia i standaryzuje mające coraz większe znaczenie dokumentowanie przebiegu choroby (patrz także odpowiedni rozdział „Ocena aktywności i wpływu oraz kontrola choroby”). Ad. (3) U chorych z pokrzywką ważne jest dokładne zebranie wywiadu z uwagi na znaczne zróżnicowanie czynników prowadzących do zaostrzenia choroby. Dalsze badania diagnostyczne mające na celu określenie czynników wywołujących u chorych z długotrwale utrzymującą się i niekontrolowaną chorobą należy dokładnie zaplanować.

W ostatnich dekadach dokonał się znaczny postęp w zakresie identyfikacji przyczyn różnych typów i podtypów pokrzywki, np. CSU [33-35]. Jako przyczyny CU opisano między innymi reakcje autoimmunologiczne wywołane czynnościowymi autoprzeciwciałami skierowanymi przeciwko receptorowi IgE o wysokim powinowactwie lub autoprzeciwciałami IgE skierowanymi przeciwko autoantygenom, pseudoalergię (niealergiczne reakcje nadwrażliwości) na pokarmy lub leki oraz ostre lub przewlekłe zakażenia (np. Helicobacter pylori lub Anisakis simplex) (tab. 6). $\mathrm{W}$ różnych opracowaniach podano jednak znacznie różniące się dane dotyczące częstości występowania poszczególnych przyczyn wywołujących pokrzywkę. Odzwierciedla to także różnice pomiędzy różnymi regionami świata, związane np. z dietą czy epidemiologią zakażeń. W związku z tym należy pamiętać, że nie u wszystkich chorych należy rozważyć wszystkie możliwe czynniki przyczynowe, a pierwszym etapem diagnostyki jest zebranie wywiadu obejmującego następujące informacje:

1) czas początku choroby,

2) kształt, wielkość, częstość występowania lub czas utrzymywania się i umiejscowienie bąbli,

3) towarzyszący obrzęk naczynioruchowy,

4) objawy towarzyszące, takie jak bóle kości lub stawów, gorączka, kurczowe bóle jamy brzusznej,

5) wywiad dotyczący występowania bąbli i obrzęku naczynioruchowego w rodzinie i u chorego,

6) wywoływanie objawów przez czynniki fizyczne lub wysiłek,

7) występowanie objawów w zależności od pory dnia, weekendów, cyklu menstruacyjnego, wakacji oraz podróży zagranicznych,

8) występowanie objawów w zależności od przyjmowanych pokarmów lub leków (np. NLPZ, inhibitorów ACE),

9) występowanie objawów w zależności od zakażeń, stresu,

10) wcześniejsze lub obecne alergie, zakażenia, choroby wewnętrzne lub autoimmunologiczne, objawy ze strony żołądka lub jelit albo inne choroby,
11) wywiad społeczny i zawodowy, zajęcia w czasie wolnym,

12) wcześniejsze leczenie i odpowiedź na wcześniejsze leczenie, w tym dawki leków i czas trwania terapii,

13) wcześniejsze badania diagnostyczne i ich wyniki.

Drugim etapem diagnostyki jest badanie przedmiotowe chorego. W każdym przypadku stwierdzenia wskazań na podstawie wywiadu lub badania przedmiotowego należy wykonać odpowiednie dodatkowe badania diagnostyczne. Jak przedstawiono na rycinie 1 i w tabeli 6 , wybór badań diagnostycznych w znacznym stopniu zależy od charakterystyki podtypu pokrzywki.

\begin{tabular}{|c|c|c|}
\hline \multicolumn{3}{|c|}{$\begin{array}{l}\text { Czy u pacjentów z przewlekłą pokrzywką spontaniczną } \\
\text { należy rozważać diagnostykę różnicową? }\end{array}$} \\
\hline $\begin{array}{l}\text { Zalecamy, aby u wszystkich pacjentów } \\
\text { z objawami podmiotowymi lub przedmio- } \\
\text { towymi sugerującymi przewlekłą } \\
\text { pokrzywkę rozważać diagnostykę różnico- } \\
\text { wą zgodnie z zalecanym algorytmem } \\
\text { (w oparciu o konsensus) }\end{array}$ & $\uparrow \uparrow$ & $\begin{array}{c}\text { Konsensus } \\
>90 \%\end{array}$ \\
\hline \multicolumn{3}{|c|}{$\begin{array}{l}\text { Jakie rutynowe badania diagnostyczne należy wykonać } \\
\text { u pacjentów z przewlekłą pokrzywką spontaniczną? }\end{array}$} \\
\hline $\begin{array}{l}\text { Zalecamy wykonanie ograniczonych } \\
\text { badań. Podstawowe badania obejmują } \\
\text { morfologię krwi obwodowej z rozmazem } \\
\text { oraz CRP i/lub OB (w oparciu o konsensus). } \\
\text { W przypadku CSU zalecamy wykonanie } \\
\text { dalszych badań diagnostycznych w opar- } \\
\text { ciu o wywiad i badania przedmiotowe, } \\
\text { zwłaszcza u chorych z długo utrzymującą } \\
\text { się i/lub niekontrolowaną chorobą } \\
\text { (w oparciu o konsensus) }\end{array}$ & 个个 & $\begin{array}{l}\text { Konsensus } \\
>90 \%\end{array}$ \\
\hline \multicolumn{3}{|c|}{$\begin{array}{l}\text { Czy u pacjentów z przewlekłą pokrzywką indukowalną } \\
\text { należy wykonać rutynowe badania diagnostyczne? }\end{array}$} \\
\hline $\begin{array}{l}\text { Zalecamy wykonanie testów prowokacyj- } \\
\text { nych w ramach diagnostyki przewlekłej } \\
\text { pokrzywki indukowalnej. } \\
\text { Zalecamy wykonanie testów prowoka- } \\
\text { cyjnych z pomiarami wartości progowych } \\
\text { oraz UCT odpowiednio do oceny aktywno- } \\
\text { ści i kontroli choroby u chorych z przewle- } \\
\text { kłą indukowalną pokrzywką (w oparciu } \\
\text { o konsensus) }\end{array}$ & $\uparrow \uparrow$ & $\begin{array}{c}\text { Konsensus } \\
>90 \%\end{array}$ \\
\hline
\end{tabular}

Intensywne i kosztowne ogólne programy badań przesiewowych, które mają na celu wykrycie przyczyn pokrzywki, są zdecydowanie niezalecane. Czynniki wymienione $\mathrm{w}$ tabeli 6 należy analizować $\mathrm{w}$ ramach poszerzonych programów diagnostycznych jedynie w oparciu o wywiad. Alergia typu I jest wyjątkowo rzadko przyczyną CSU. W przeciwieństwie do tego pseudoalergiczne (niealergiczne reakcje nadwrażliwości) reakcje na NLPZ 
lub pokarmy są częściej związane z CSU. Rozpoznanie należy opierać na informacjach $\mathrm{z}$ wywiadu dotyczących przyjmowania NLPZ lub na protokole odpowiednej do pseudoalergii diety eliminacyjnej. We wcześniejszych badaniach wykazano, że przyczyny pokrzywki obejmują zakażenia bakteryjne, wirusowe i grzybicze oraz infesta- cje pasożytnicze, wywołane np. H. pylori, paciorkowcami, gronkowcami, Yersinia, Giardia lamblia, Mycoplasma pneumoniae, wirusami zapalenia wątroby, norovirus, parvovirus B19, Anisakis simplex, Entamoeba spp., Blastocystis spp. [36-38]. Częstość występowania i związek zakażeń z pokrzywką różni się istotnie pomiędzy różny-

TABELA 6. Zalecane badania diagnostyczne w najczęstszych podtypach pokrzywki

\begin{tabular}{|c|c|c|c|}
\hline Туру & Podtypy & $\begin{array}{l}\text { Rutynowe badania } \\
\text { diagnostyczne (zalecane) }\end{array}$ & $\begin{array}{l}\text { Rozszerzony program badań diagnostycznych } \\
\text { (na podstawie wywiadu) } \\
\text { w celu identyfikacji przyczyn lub czynników wywołujących } \\
\text { oraz wykluczenia innych chorób w ramach rozpoznania } \\
\text { różnicowego w zależności od wskazań }\end{array}$ \\
\hline \multirow[t]{2}{*}{$\begin{array}{l}\text { Pokrzywka } \\
\text { spontaniczna }\end{array}$} & $\begin{array}{l}\text { Ostra spontanicz- } \\
\text { na pokrzywka }\end{array}$ & Brak & Brak $^{b}$ \\
\hline & CSU & $\begin{array}{l}\text { Morfologia z rozmazem, } \\
\text { OB i/lub CRP }\end{array}$ & $\begin{array}{l}\text { Unikanie podejrzanych czynników wywołujących (np. leków); } \\
\text { wykonanie badań diagnostycznych w kierunku (kolejność nie } \\
\text { oznacza preferencji): (i) chorób zakaźnych (np. Helicobacter pylori); } \\
\text { (ii) czynnościowych autoprzeciwciał (np. test skórny z surowicą } \\
\text { autologiczną); (iii) chorób tarczycy (stężenia hormonów tarczycy } \\
\text { oraz obecność autoprzeciwciał); (iv) alergii (testy skórne i/lub testy } \\
\text { unikania alergenu, np. dieta eliminacyjna); (v) współistniejącej } \\
\text { ClndU, patrz niżej [69]; (vi) ciężkiej choroby systemowej (np. tryp- } \\
\text { taza); (vii) innych przyczyn (np. biopsja skóry objętej zmianami) }\end{array}$ \\
\hline \multirow[t]{9}{*}{$\begin{array}{l}\text { Pokrzywka } \\
\text { indukowalna }\end{array}$} & $\begin{array}{l}\text { Pokrzywka } \\
\text { z zimna }\end{array}$ & $\begin{array}{l}\text { Prowokacja zimnem i okreś- } \\
\text { lenie wartości progowej,cd }\end{array}$ & $\begin{array}{l}\text { Morfologia krwi z rozmazem i OB lub CRP, wykluczenie innych } \\
\text { chorób, zwłaszcza zakażeń [168] }\end{array}$ \\
\hline & $\begin{array}{l}\text { Opóźniona } \\
\text { pokrzywka z ucisku }\end{array}$ & $\begin{array}{l}\text { Test ucisku i określenie } \\
\text { wartości progowej,cd }\end{array}$ & Brak \\
\hline & Pokrzywka z ciepła & $\begin{array}{l}\text { Prowokacja ciepłem i okreś- } \\
\text { lenie wartości progowejc,d }\end{array}$ & Brak \\
\hline & $\begin{array}{l}\text { Pokrzywka } \\
\text { słoneczna }\end{array}$ & $\begin{array}{l}\text { Test z UV i światłem } \\
\text { widzialnym o różnej długości } \\
\text { fali i określenie wartości } \\
\text { progowejc }\end{array}$ & Wykluczenie innych chorób skóry wywoływanych światłem \\
\hline & $\begin{array}{l}\text { Dermografizm } \\
\text { objawowy }\end{array}$ & $\begin{array}{c}\text { Wywołanie dermogra- } \\
\text { fizmu i określenie wartości } \\
\text { progowej, }{ }^{c, d}\end{array}$ & Morfologia krwi z rozmazem, OB lub CRP \\
\hline & $\begin{array}{c}\text { Obrzęk } \\
\text { naczynioruchowy } \\
\text { wibracyjny }\end{array}$ & $\begin{array}{l}\text { Test z wibracją, np. Vortex } \\
\text { lub mikser }^{\mathrm{d}}\end{array}$ & Brak \\
\hline & $\begin{array}{c}\text { Pokrzywka } \\
\text { akwageniczna }\end{array}$ & Testy prowokacji & Brak \\
\hline & $\begin{array}{c}\text { Pokrzywka } \\
\text { cholinergiczna }\end{array}$ & $\begin{array}{l}\text { Testy prowokacji i określenie } \\
\text { wartości progowej }^{\text {d }}\end{array}$ & Brak \\
\hline & $\begin{array}{l}\text { Pokrzywka } \\
\text { kontaktowa }\end{array}$ & Testy prowokacji & Brak \\
\hline
\end{tabular}

CRP - białko C-reaktywne, OB - odczyn Biernackiego.

${ }^{a} W$ zależności od podejrzewanej przyczyny.

${ }^{\mathrm{b}} 0$ ile nie ma silnych sugestii w wywiadzie, np. alergii.

'Wszystkie badania wykonuje się przy różnych poziomach potencjalnych czynników wywołujących w celu określenia wartości progowej.

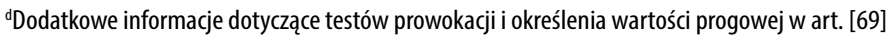


mi grupami chorych oraz regionami geograficznymi. $\mathrm{Na}$ przykład, Anisakis simplex, nicienie występujące w rybach morskich były rozważane jako możliwa przyczyna nawracającej ostrej pokrzywki spontanicznej w tych obszarach świata, gdzie często spożywa się surowe ryby [39, 40]. Związek z pokrzywką zakażenia $H$. pylori oraz zakażeń zębów, ucha, nosa i gardła także różni się pomiędzy poszczególnymi grupami chorych [38, 41-44]. Sformułowanie ostatecznych zaleceń dotyczących roli zakażeń w rozwoju pokrzywki wymaga dalszych badań.

Nie sugeruje się wykonywania rutynowych badań w kierunku nowotworów złośliwych w ramach diagnostyki przyczyn pokrzywki. Na Tajwanie odnotowano nieco częstsze występowanie tej zależności [45], jednak brakuje wystarczających dowodów naukowych wskazujących na związek przyczynowy pomiędzy pokrzywką a chorobami nowotworowymi. Wykluczenie nowotworów złośliwych jest jednak konieczne u chorych, u których wywiad wskazuje na taką możliwość (np. nagłe zmniejszenie masy ciała).

Obecnie jedyne dostępne ogólne badania przesiewowe w kierunku autoprzeciwciał przeciwko IgE lub FceR1 (receptor IgE o wysokim powinowactwie) obejmują testy skórne $\mathrm{z}$ autologiczną surowicą (autologous serum skin test - ASST) oraz testy aktywacji bazofilów (basophil activation test - BAT). ASST jest nieswoistym badaniem przesiewowym, oceniającym obecność w surowicy czynników uwalniających histaminę wszystkich typów, nie tylko autoprzeciwciał uwalniających histaminę. Z uwagi na możliwość przeniesienia zakażenia, jeśli przez pomyłkę chory otrzymałby surowicę innego chorego, badanie ASST należy wykonywać z największą ostrożnością. Temat ten został szczegółowo omówiony w oddzielnej publikacji EAACI/GA²LEN $[46,47]$.

TABELA 7. Skala aktywności pokrzywki (UAS7) do oceny aktywności choroby u pacjentów z CSU. Suma wartości: 0-6 dla każdego dnia sumuje się w ciągu tygodnia (maksymalnie 42)

\begin{tabular}{|c|c|c|}
\hline Punkty & Bąble & Swiąd \\
\hline 0 & Brak & Brak \\
\hline 1 & $\begin{array}{c}\text { Łagodne } \\
\text { (<20 bąbli/24 godz.) }\end{array}$ & $\begin{array}{l}\text { Łagodny (obecny, ale nie } \\
\text { uciążliwy lub dokuczliwy) }\end{array}$ \\
\hline 2 & $\begin{array}{c}\text { Umiarkowane } \\
\text { (20-50 bąbli/ } \\
24 \text { godz.) }\end{array}$ & $\begin{array}{c}\text { Umiarkowany (dokucz- } \\
\text { liwy, ale niewpływający } \\
\text { na normalne aktywności } \\
\text { życiowe lub sen) }\end{array}$ \\
\hline 3 & $\begin{array}{c}\text { Intensywne } \\
\text { (> } 50 \text { bąbli/24 godz. } \\
\text { lub duże obszary } \\
\text { zlewających się bąbli) }\end{array}$ & $\begin{array}{c}\text { Intensywny (bardzo } \\
\text { nasilony świąd, na tyle } \\
\text { dokuczliwy, że wpływa } \\
\text { na normalne aktywności } \\
\text { życiowe lub sen) }\end{array}$ \\
\hline
\end{tabular}

Testy BAT oceniają uwalnianie histaminy lub nadmierną aktywność markerów bazofilów dawcy w odpowiedzi na stymulację surowicą pacjentów z CSU. Test ten może pomóc także w ocenie aktywności choroby u pacjentów z pokrzywką $[48,49]$, a także w diagnostyce pokrzywki autoimmunologicznej [50]. Ponadto BAT można zastosować jako marker odpowiedzi na cyklosporynę A lub omalizumab $[51,52]$.

Część badaczy wykazała obecność u niektórych pacjentów z CSU bazopenii we krwi oraz obniżone mediowane przez receptor dla IgE wydzielanie histaminy przez bazofile w odpowiedzi na działanie przeciwciał anty-IgE. Bazofile z krwi wykrywa się także w zmianach skórnych u pacjentów z CSU [19]. Z kolei remisja CSU wiąże się ze zwiększeniem liczby bazofilów we krwi oraz warunkowaną przez receptor IgE odpowiedzią na histaminę $[53,54]$. Zwiększenie liczby bazofilów obserwuje się także w trakcie leczenia anty-IgE [55]. Zjawisko to wymaga jednak dalszych badań, obecnie brak podstaw do sformułowania zaleceń diagnostycznych $\mathrm{z}$ tym związanych. Należy jednak odnotować, że niska liczba bazofilów we krwi nie powinna być przyczyną dalszych badań diagnostycznych. Wiadomo też, że poziom D-dimerów jest istotnie zwiększony u chorych $\mathrm{z}$ aktywną CSU i zmniejsza się wraz z odpowiedzią kliniczną na leczenie omalizumabem. Znaczenie tej obserwacji nie jest jasne, obecnie jednak nie zaleca się oznaczenia stężenia D-dimerów [56, 57].

\subsubsection{Ocena aktywności, wpływu i kontroli choroby}

Aktywność choroby w przebiegu spontanicznej pokrzywki należy oceniać zarówno w praktyce klinicznej, jak i w ramach badań przy użyciu UAS7 (tab. 7), ujednoliconego i prostego systemu oceny, zaproponowanego w ostatniej wersji wytycznych i zwalidowanego $[58,59]$. System UAS7 opiera się na ocenie najważniejszych objawów podmiotowych i przedmiotowych pokrzywki (bąble i świąd) udokumentowanych przez chorych, co sprawia, że jest on szczególnie wartościowy. Zastosowanie UAS7 ułatwia porównanie wyników badań pochodzących z różnych ośrodków. Aktywność pokrzywki ulega częstym zmianom, dlatego najlepszym sposobem ogólnego pomiaru jest zalecenie choremu dokumentowania własnych ocen $z$ ostatnich 24 godzin, dokonywanych raz dziennie przez kilka dni. Wynik UAS7 będący sumą ocen z kolejnych 7 dni należy stosować w codziennej praktyce klinicznej do oceny aktywności choroby oraz odpowiedzi na leczenie u pacjentów z CSU. U chorych z obrzękiem naczynioruchowym opracowano i zwalidowano nowy system oceny aktywności choroby, skalę aktywności obrzęku naczynioruchowego (angioedema activity sco- 
re - AAS) [60]. Poza aktywnością choroby istotne znaczenie ma też ocena wpływu choroby na jakość życia oraz kontroli choroby, zarówno w praktyce klinicznej, jak i w badaniach. W ostatnim czasie szczególnej wartości w ocenie stanu choroby nabrał test kontroli pokrzywki (urticaria control test - UCT) [61, 62]. UCT opracowano i zwalidowano w celu określenia poziomu kontroli choroby we wszystkich postaciach CU (CSU i CIndU). UCT obejmuje jedynie 4 zagadnienia $\mathrm{z}$ jasno określonymi wartościami odcięcia dla chorych $\mathrm{z}$ „dobrze kontrolowaną” $\mathrm{w}$ porównaniu $\mathrm{z}$,źle kontrolowaną" chorobą; jest w związku $\mathrm{z}$ tym odpowiedni do stosowania $\mathrm{w}$ opiece nad chorymi z pokrzywką $\mathrm{w}$ rutynowej praktyce klinicznej. Wartość graniczna dla dobrze kontrolowanej choroby wynosi 12 z 16 możliwych punktów. Pomaga to w podejmowaniu decyzji terapeutycznych.

Aktywność choroby, jej wpływ na stan chorego oraz kontrolę choroby należy ocenić na pierwszej i każdej kolejnej wizycie, mając na uwadze, że narzędzia, takie jak UAS, można stosować jedynie prospektywnie, natomiast inne, takie jak UCT, umożliwiają ocenę retrospektywną. U chorych z CU należy w tym celu stosować walidowane narzędzia, takie jak UAS7, AAS, CU-Q2oL, AE-QoL i UCT.

\section{Czy u chorych z przewlekłą pokrzywką należy oceniać} aktywność, wpływ i kontrolę choroby?

\begin{tabular}{l|c|c|}
\hline $\begin{array}{l}\text { Zalecamy, aby u chorych z przewlekłą } \\
\text { pokrzywką oceniać aktywność, wpływ } \\
\text { i kontrolę choroby na każdej wizycie } \\
\text { (w oparciu o konsensus) }\end{array}$ & $\uparrow \uparrow$ & $\begin{array}{c}\text { Konsensus } \\
>90 \%\end{array}$ \\
\hline $\begin{array}{l}\text { Jakie narzędzia należy stosować do oceny i monitorowania } \\
\text { aktywności choroby u pacjentów z przewlekłą spontaniczną } \\
\text { pokrzywką? }\end{array}$ & $\uparrow$ & $\begin{array}{c}\text { Konsensus } \\
>90 \%\end{array}$ \\
$\begin{array}{l}\text { Sugerujemy stosowanie skali oceny } \\
\text { aktywności pokrzywki (UAS7), skali oceny } \\
\text { aktywności obrzęku naczynioruchowego } \\
\text { (AAS) do oceny aktywności choroby } \\
\begin{array}{l}\text { u pacjentów z pokrzywką przewlekłą } \\
\text { spontaniczną (w oparciu o konsensus) }\end{array}\end{array}$ & & \\
\hline
\end{tabular}

Jakie narzędzia należy stosować do oceny i monitorowania pogorszenia jakości życia u pacjentów z przewlekłą spontaniczną pokrzywką?

\begin{tabular}{l|c|c}
$\begin{array}{l}\text { Sugerujemy stosowanie kwestionariusza } \\
\text { jakości życia u chorych z przewlekłą }\end{array}$ & $\uparrow$ & $\begin{array}{l}\text { Konsensus } \\
>90 \%\end{array}$ \\
$\begin{array}{l}\text { pokrzywką (CU-Q2oL) oraz kwestionariu- } \\
\text { sza jakości życia u chorych z obrzękiem }\end{array}$ & & \\
naczynioruchowym (AE-QoL) do oceny & & \\
pogorszenia jakości życia u pacjentów & & \\
z pokrzywką przewlekłą spontaniczną & & \\
(w oparciu o konsensus) & &
\end{tabular}

\begin{tabular}{|c|c|c|}
\hline $\begin{array}{l}\text { Jakie narzędzia należy stosować do oceny } \\
\text { kontroli choroby u pacjentów z pokrzywk } \\
\text { spontaniczną? }\end{array}$ & & $\begin{array}{l}\text { rowania } \\
\text { ekłą }\end{array}$ \\
\hline $\begin{array}{l}\text { Sugerujemy stosowanie testu kontroli } \\
\text { pokrzywki (UCT) do oceny kontroli choroby } \\
\text { u pacjentów z pokrzywką przewlekłą } \\
\text { spontaniczną (w oparciu o konsensus) }\end{array}$ & $\uparrow$ & $\begin{array}{c}\text { Konsensus } \\
>90 \%\end{array}$ \\
\hline
\end{tabular}

U pacjentów z CIndU w celu oceny aktywności choroby należy określić wartość progową dla czynnika (czynników) wywołującego (wywołujących), np. krytyczną temperaturę i wartość progową czasu stymulacji w teście prowokacji zimnem u chorych z pokrzywką z zimna. Wartości progowe umożliwiają zarówno pacjentom, jak i lekarzom ocenę aktywności choroby i odpowiedzi na leczenie [63-68].

\subsection{BADANIA DIAGNOSTYCZNE U CHORYCH ZCIndU}

Rutynowe badania diagnostyczne u pacjentów z CIndU należy wykonywać zgodnie z uzgodnionymi zaleceniami dotyczącymi definicji, badań diagnostycznych i leczenia chorych z CIndU [69]. Diagnostyka w przypad$\mathrm{ku}$ CIndU ma na celu określenie podtypu CIndU oraz wartości progowych czynników wywołujących [69]. Ten ostatni parametr jest bardzo ważny, ponieważ umożliwia ocenę aktywności choroby i odpowiedzi na leczenie. W większości typów CIndU w międzyczasie stały się dostępne walidowane narzędzia do przeprowadzania testów prowokacyjnych [69]. Przykłady obejmują pokrzywkę z zimna i ciepła, dla których dostępne jest urządzenie do testów prowokacji oparte na elemencie Peltiera (TempTest ${ }^{\oplus}$ ) [70], dermografizm objawowy, w przypadku którego opracowano dermografometr $\left(\right.$ FricTest $\left.^{\oplus}\right)[71,72]$, oraz pokrzywkę opóźnioną z ucisku. W przypadku pokrzywki cholinergicznej dostępny jest test stopniowanej prowokacji z wykorzystaniem metod ambulatoryjnych, np. ergometrii kontrolowanej tętnem $[66,73]$. U chorych z pokrzywką kontaktową lub akwageniczną należy wykonywać odpowiednie prowokacyjne testy skórne [69].

\subsection{ROZPOZNANIE U DZIECI}

Pokrzywka może wystąpić we wszystkich grupach wiekowych, w tym u niemowląt i małych dzieci. Dotychczas dostępnych jest niewiele danych dotyczących CSU u dzieci, jednak ostatnie badania pokazują, że częstość występowania CIndU i CSU oraz przyczyny wywołujące CSU są bardzo podobne jak u dorosłych, z niewielkimi jedynie różnicami [74-77].

W związku z tym strategia postępowania diagnostycznego u dzieci powinna być podobna jak u dorosłych. 
Cele badań diagnostycznych u dzieci z CSU są takie same jak u dorosłych: (i) należy wykluczyć inne rozpoznania w ramach diagnostyki różnicowej, ze szczególnym uwzględnieniem okresowych zespołów zależnych od kriopiryny (CAPS). CAPS jest rzadką chorobą przebiegającą ze zmianami skórnymi przypominającymi pokrzywkę, występującą u dzieci i młodzieży [78]. (ii) Na ile to możliwe, a zależy to od wieku dziecka, aktywność, wpływ i kontrolę choroby u dzieci należy oceniać przy użyciu narzędzi podobnych jak u dorosłych, choć jak dotąd nie opracowano walidowanych, dedykowanych do stosowania u dzieci narzędzi swoistych dla tej choroby. (iii) Należy zidentyfikować czynniki wywołujące zaostrzenia oraz, tam gdzie są odpowiednie wskazania, należy poszukiwać też przyczyn choroby, które wydają się podobne jak u dorosłych. U dzieci z CIndU należy wykonać podobne testy prowokacji oraz badania określające wartości progowe czynników wywołujących.

\section{LECZENIE POKRZYWKI}

\subsection{UWAGI OGÓLNE}

1. Celem leczenia jest ustąpienie objawów choroby.

2. Leczenie chorych z CU może obejmować:

a) określenie i eliminację przyczyn choroby,

b) unikanie czynników wywołujących,

c) wywoływanie tolerancji i/lub

d) stosowanie leczenia farmakologicznego w celu zapobiegania uwalnianiu mediatorów z komórek tucznych i/lub następstw działania tych mediatorów.

3. Leczenie należy prowadzić zgodnie z podstawowymi zasadami terapii, tzn. jego intensywność powinna być tak duża jak to konieczne i tak mała jak to możliwe. Może to oznaczać zwiększanie lub zmniejszanie intensywności leczenia w ramach algorytmu stosownie do przebiegu choroby.

\section{Czy celem leczenia chorych z pokrzywką powinna być} całkowita kontrola objawów?

Zalecamy, aby celem leczenia chorych z pokrzywką była całkowita kontrola objawów choroby, uwzględniając w możliwie jak największym stopniu bezpieczeństwo i jakość życia każdego pacjenta (w oparciu o konsensus)

\subsection{IDENTYFIKACJA I ELIMINACJA PRZYCZYN CHOROBY ORAZ UNIKANIE CZYNNIKÓW WYWOŁUJĄCYCH}

Podstawowym warunkiem eliminacji przyczyn choroby jest dokładna diagnostyka. Określenie przyczyny CU jest jednak w większości przypadków trudne, na przykład zakażenie może być czynnikiem wywołującym chorobę, zaostrzającym jej przebieg lub niezwiązanym z pokrzywką. Jedynym wyraźnym dowodem przyczynowego charakteru podejrzanego lub wywołującego czynnika jest uzyskanie remisji objawów po eliminacji oraz nawrót objawów po ponownej ekspozycji w trakcie podwójnie zaślepionego testu prowokacji. Ponieważ w każdym czasie może dojść do spontanicznej remisji pokrzywki, eliminacja czynnika podejrzanego lub wywołującego może być jedynie przypadkowo zbieżna.

\subsubsection{Leki}

W przypadku pojawienia się w trakcie diagnostyki podejrzenia przyczynowej roli leku należy całkowicie zaprzestać jego podawania lub zamienić go na lek $\mathrm{z}$ innej grupy, jeśli jest on niezbędny. Leki wywołujące niealergiczne reakcje nadwrażliwości (przykładem są NLPZ) mogą nie być jedynie czynnikiem wyzwalającym, ale także nasilającym istniejącą wcześniej CSU [79], w związku z tym eliminacja czynnika w tym ostatnim przypadku może jedynie złagodzić objawy u części chorych.

\section{Czy chorym z pokrzywką przewlekłą spontaniczną należy zalecić zaprzestanie podawania leku, który podejrzewa się o zaostrzenie objawów choroby?}

Zalecamy, aby doradzić chorym z po-

krzywką przewlekłą spontaniczną zaprze-

stanie podawania leku, który podejrzewa się o zaostrzenie objawów choroby, np. NLPZ (w oparciu o konsensus)

\subsubsection{Czynniki fizyczne}

Unikanie czynników fizycznych w leczeniu pacjentów z CIndU jest konieczne, ale w większości przypadków jest to bardzo trudne do uzyskania. Szczegółowe informacje na temat właściwości fizycznych poszczególnych czynników stymulujących powinny dostarczyć pacjentowi wystarczającej wiedzy, aby mógł on rozpoznać i kontrolować ekspozycję w trakcie normalnych aktywności życiowych. W związku z tym ważne jest na przykład wskazanie w przypadku pokrzywki opóźnionej z ucisku oraz objawowego dermografizmu, że ciśnienie definiuje się jako siłę wywieraną na określony obszar i podjęcie prostych działań, takich jak poszerzenie uchwytów ciężkich toreb w przypadku pokrzywki z ucisku lub zmniejszenie tarcia w przypadku objawowego dermografizmu, może pomóc w zapobieganiu występowaniu objawów. Podobne zasady dotyczą pokrzywki z zimna, w której należy pamiętać o wpływie zimnego wiatru. $Z$ kolei u pacjentów z pokrzywką słoneczną istotne dla wyboru odpowiednich 
filtrów przeciwsłonecznych lub w podjęciu decyzji o zastosowaniu żarówek z filtrem UVA może być określenie dokładnego zakresu długości fali wywołującej objawy. U wielu pacjentów wartość progowa odpowiedniego fizycznego czynnika wywołującego może być jednak mała i całkowite unikanie występowania objawów może być w praktyce niemożliwe. Na przykład ciężka postać objawowego dermografizmu jest czasami mylona z CSU z uwagi na występowanie pozornie spontanicznej pokrzywki w miejscach, gdzie nawet obszerne ubrania pocierają skórę lub niezamierzone drapanie się przez chorego łatwo prowadzi do powstawania bąbli w tym obszarze.

\subsubsection{Eradykacja czynników zakaźnych i leczenie procesów zapalnych}

W przeciwieństwie do CIndU, w przypadku CSU często podaje się, że jest ona związana $\mathrm{z}$ różnymi chorobami zapalnymi i zakaźnymi. W niektórych przypadkach ma to istotne znaczenie, natomiast wyniki części badań są sprzeczne, a zastosowana w nich metodologia wykazuje słabości. Zakażenia, które należy odpowiednio leczyć, obejmują zakażenia przewodu pokarmowego, takie jak zakażenie $H$. pylori lub bakteryjne zakażenia nosogardzieli [80] (nawet jeśli związek z pokrzywką nie jest jasny u poszczególnych chorych, a metaanaliza wykazuje słabe dowody na skuteczność eradykacji [80], należy jednak wyeliminować zakażenie $H$. pylori z uwagi na sugestie dotyczące jego związku z rakiem żołądka [81]). Pasożyty jelitowe, rzadka przyczyna CSU w krajach rozwiniętych, należy wyeliminować, jeśli istnieją odpowiednie wskazania $[80,82]$. W przeszłości kandydozę jelitową uznawano za bardzo ważny czynnik wywołujący CSU [80], jednak wyniki ostatnich badań nie potwierdzają jego roli przyczynowej [83]. Poza chorobami zakaźnymi wykazano też, że potencjalnymi czynnikami wywołującymi CSU są przewlekłe procesy zapalne w przebiegu wielu innych chorób. Odnosi się to zwłaszcza do zapalenia błony śluzowej żołądka, choroby refluksowej przełyku albo zapalenia przewodu lub pęcherzyka żółciowego [84, 85]. Podobnie jak w przypadku zakażeń, nie jest jednak łatwo określić, czy któryś z tych procesów jest przyczyną CSU, ale należy podjąć odpowiednie leczenie, ponieważ wiele $\mathrm{z}$ nich może wiązać się $\mathrm{z}$ występowaniem nowotworów złośliwych.

\subsubsection{Zmniejszenie stresu fizycznego i emocjonalnego}

Mechanizm zaostrzeń wywoływanych stresem nie jest do końca poznany, jednak niektóre dowody wskazują, że aktywność i nasilenie choroby korelują z poziomem stresu [86]. Odnosi się to zarówno do stresu emocjonalnego, jak i fizycznego, które w niektórych jednostkach choro- bowych mogą prowadzić do rozwoju objawów, takich jak pokrzywka cholinergiczna [87].

\subsubsection{Zmniejszenie miana czynnościowych autoprzeciwciał}

Wykazano, że bezpośrednie zmniejszenie miana czynnościowych autoprzeciwciał po zastosowaniu plazmaferezy może przynieść przejściowe korzyści u niektórych chorych, z najbardziej nasiloną chorobą [88]. Z uwagi na ograniczone doświadczenie i wysokie koszty sugeruje się, że leczenie to należy stosować u pacjentów z CSU z obecnością autoprzeciwciał, nieodpowiadających na inne metody leczenia.

\subsubsection{Leczenie dietetyczne}

Alergia pokarmowa IgE-zależna jest niezwykle rzadką przyczyną CSU $[84,89]$. W takim przypadku należy możliwie w największym stopniu wyeliminować swoiste alergeny pokarmowe, co może doprowadzić do remisji w ciągu mniej niż 24 godzin. U niektórych chorych z CSU obserwowano pseudoalergiczne reakcje (reakcje nadwrażliwości przebiegające bez udziału IgE) na naturalnie występujące składniki pokarmowe, a w niektórych przypadkach na dodatki do żywności [84, 89-93]. W różnych krajach badano stosowanie diety pozbawionej pseudoalergenów, zawierającej jedynie niewielkie stężenia naturalnych i sztucznych pseudoalergenów pokarmowych [94]. Skuteczna u tych chorych może być także dieta z niską zawartością histaminy [95]. Zastosowanie tego rodzaju diet jest kontrowersyjne i jak dotąd niepotwierdzone w dobrze zaprojektowanych, podwójnie zaślepionych, kontrolowanych placebo badaniach klinicznych. Jednak po ich zastosowaniu należy kontynuować dietę przez minimum 2-3 tygodnie, zanim pojawią się pierwsze korzyści. Należy też podkreślić, że takie leczenie wymaga współpracy ze strony pacjenta, a odsetek skuteczności różni się istotnie $\mathrm{z}$ uwagi na różnice regionalne dotyczące pokarmów i zwyczajów żywieniowych. Konieczne są dalsze badania nad wpływem naturalnych i sztucznych składników pokarmowych na wywoływanie pokrzywki.

\subsection{WYWOŁYWANIE STANU TOLERANCJ}

W niektórych typach pokrzywki przydatne może być wywołanie stanu tolerancji, np. w przypadku pokrzywki z zimna, pokrzywki cholinergicznej i pokrzywki słonecznej, w której nawet przyspieszone leczenie z użyciem UVA jest skuteczne w ciągu 3 dni [96]. Wywołana tolerancja utrzymuje się jednak tylko kilka dni, w związku z tym wymagana jest stała codzienna ekspozycja na progowe wartości czynnika stymulujące- 
go. Chorzy często nie akceptują procedury wywołania i utrzymania tolerancji, np. w przypadku pokrzywki z zimna, gdzie wymaga to codziennych zimnych kąpieli lub prysznica.

\subsection{OBJAWOWE LECZENIE FARMAKOLOGICZNE}

Podstawową zasadą leczenia farmakologicznego jest określenie jako jej celu całkowitego ustąpienia objawów. Inną zasadą farmakoterapii jest zastosowanie leczenia o intensywności tak dużej jak to konieczne i tak małej jak to możliwe. W związku z tym zakres działania i wybór leku może różnić się w przebiegu choroby.

Głównym efektem terapii, których celem jest złagodzenie objawów choroby, jest zmniejszenie aktywności mediatorów komórek tucznych, takich jak histamina, PAF i inne, w narządach docelowych. Wiele objawów pokrzywki jest głównie następstwem działania histaminy na receptory $\mathrm{H}_{1}$ zlokalizowane na komórkach śródbłonka (bąble) i na nerwach czuciowych (neurogenny rumień i świąd). W związku z tym szczególne znaczenie $\mathrm{w}$ leczeniu chorych z pokrzywką ma ciągłe podawanie leków przeciwhistaminowych blokujących receptory $\mathrm{H}_{1}$ (dostępne są dane dotyczące bezpieczeństwa leczenia prowadzonego w sposób ciągły przez kilka lat). Zasadność ciągłego podawania leków przeciwhistaminowych blokujących receptory $\mathrm{H}_{1}$ potwierdzają nie tylko wyniki badań klinicznych [97, 98], ale także mechanizm działania tych leków polegający m.in. na tym, że są one odwrotnymi agonistami o preferencyjnym powinowactwie do receptorów histaminowych $\mathrm{H}_{1}$ w stanie nieaktywnym, stabilizując je w tej konformacji i zmieniając stan równowagi w kierunku stanu nieaktywnego.

Inne mediatory komórek tucznych (PAF, leukotrieny, cytokiny) mogą także być zaangażowane i można zaobserwować naciek komórkowy obejmujący bazofile, limfocyty i eozynofile [99]. Może to wiązać się z dużą skutecznością krótkotrwałego podania kortykosteroidów i stosunkową opornością na leki przeciwhistaminowe.

Przytoczone ogólne uwagi dotyczące farmakoterapii odnoszą się do wszystkich postaci ostrej i przewlekłej pokrzywki. Różnica pomiędzy pokrzywką spontaniczną a CIndU jest jednak taka, że w niektórych postaciach pokrzywki fizykalnej, np. w pokrzywce z zimna, skuteczne może okazać się leczenie "na żądanie” zamiast ciągłego podawania leków. Dotyczy to zwłaszcza sytuacji, gdy chory wie o zaplanowanym działaniu czynnika wyzwalającego, np. oczekiwanej ekspozycji na zimno, gdy idzie latem popływać; $w$ tych przypadkach przyjęcie leku przeciwhistaminowego 2 godziny przed aktywnością może być wystarczające.

Leki przeciwhistaminowe dostępne są w leczeniu chorych z pokrzywką od lat 50. XX wieku. Starsze leki przeciwhistaminowe pierwszej generacji wykazywały silny efekt antycholinergiczny i działanie uspokajające (sedacyjne) na ośrodkowy układ nerwowy (OUN). Opisano także wiele interakcji z alkoholem i lekami działającymi na OUN, takimi jak leki przeciwbólowe, nasenne, uspokajające oraz poprawiające nastrój. Wpływają one także na fazę snu z szybkim ruchem gałek ocznych (rapid eye movement - REM) oraz na proces nauki i wydajność. Upośledzenie to jest szczególnie wyraźne w trakcie jednoczesnego wykonywania kilku zadań (multi-tasking) oraz złożonych zadań sensomotorycznych, takich jak prowadzenie samochodu. W publikacji przedstawiającej stanowisko GA ${ }^{2} L E N$ [100] wyraźnie zaleca się nieużywanie już leków przeciwhistaminowych pierwszej generacji w leczeniu alergii zarówno u dorosłych, jak i w szczególności u dzieci. Pogląd ten wyrażono także w wytycznych ARIA opracowanych przez Światową Organizację Zdrowia (WHO) [101]. W oparciu o silne dowody wskazujące na potencjalnie poważne działania niepożądane starych, działających uspokajająco leków przeciwhistaminowych (opisano nawet śmiertelne przedawkowania) zalecamy niestosowanie tych leków jako pierwszego wyboru w rutynowym leczeniu CU poza nielicznymi miejscami na świecie, gdzie nowoczesne leki przeciwhistaminowe drugiej generacji nie są dostępne. Działania niepożądane leków przeciwhistaminowych pierwszej generacji blokujących receptory $\mathrm{H}_{1}$ są dobrze poznane i szczególnie wyraźne w przypadku stosowania prometazyny, difenhydraminy, ketotifenu i chlorfenaminy. Leki te przechodzą przez barierę krew-mózg, wiążą się z receptorami $\mathrm{H}_{1}$ zlokalizowanymi w OUN i wpływają na neurotransmisyjne następstwa działania histaminy. Badania metodą pozytonowej tomografii emisyjnej (positron-emission tomography - PET) potwierdzają penetrację tych leków do ludzkiego mózgu, dostarczając nowego dowodu, że oddziaływanie na receptory $\mathrm{H}_{1}$ w OUN może być bezpośrednio związane z wpływem na czynność OUN [102].

Opracowanie nowoczesnych leków przeciwhistaminowych drugiej generacji przyczyniło się do powstania leków wykazujących minimalne działanie uspokajające lub jego brak i wolnych od działania antycholinergicznego. Niemniej dwa wcześniejsze nowoczesne leki przeciwhistaminowe drugiej generacji - astemizol i terfenadyna, będące prolekami, wymagającymi do pełnej aktywności metabolizmu w wątrobie - wykazywały działanie kardiotoksyczne w przypadku zablokowania metabolizmu wskutek jednoczesnego podawania inhibitorów izoenzymu 3A4 cytochromu P450 (CYP), takich jak ketokonazol lub erytromycyna. Oba leki nie są już dostępne w większości krajów i my zalecamy, aby ich nie stosować.

W ostatnich kilku dekadach uzyskano dalszy postęp w zakresie bezpieczeństwa terapii przez opracowanie znacznej liczby kolejnych nowoczesnych leków prze- 
ciwhistaminowych drugiej generacji [102]. Nie wszystkie leki przeciwhistaminowe poddano badaniom u chorych z pokrzywką; dostępnych jest jednak wiele badań $\mathrm{z}$ użyciem leków przeciwhistaminowych bez działania sedatywnego, takich jak cetyryzyna, desloratadyna, feksofenadyna, lewocetyryzyna, loratadyna, ebastyna, rupatadyna i bilastyna. Z uwagi na dobry profil bezpieczeństwa nowoczesnych leków przeciwhistaminowych drugiej generacji należy rozważyć ich stosowanie w pierwszej linii leczenia objawowego chorych z pokrzywką. Jak dotąd brakuje dobrze zaprojektowanych badań klinicznych, porównujących skuteczność i bezpieczeństwo nowoczesnych leków przeciwhistaminowych drugiej generacji u chorych z pokrzywką.

\begin{tabular}{|l|l|}
\hline \multicolumn{3}{|l|}{ Czy leki przeciwhistaminowe drugiej generacji blokujące } \\
receptory $\mathrm{H}_{1}$ powinny być preferowane w porównaniu \\
z lekami pierwszej generacji w leczeniu chorych \\
z przewlekłą pokrzywką?
\end{tabular}

Czy nowoczesne leki przeciwhistaminowe drugiej generacji blokujące receptory $\mathrm{H}_{1}$ powinny być stosowane w pierwszej linii leczenia chorych z pokrzywką?

\begin{tabular}{|c|c|c|}
\hline $\begin{array}{l}\text { Zalecamy stosowanie nowoczesnych } \\
\text { leków przeciwhistaminowych drugiej } \\
\text { generacji blokujących receptory } \mathrm{H}_{1} \\
\text { w pierwszej linii leczenia chorych z prze- } \\
\text { wlekłą pokrzywwą (w oparciu o dowody } \\
\text { ¡ konsensus) }\end{array}$ & $\uparrow \uparrow$ & $\begin{array}{c}\text { Konsensus } \\
>90 \%\end{array}$ \\
\hline \multicolumn{3}{|c|}{$\begin{array}{l}\text { Czy nowoczesne leki przeciwhistaminowe drugiej generacji } \\
\text { blokujące receptory } \mathrm{H}_{1} \text { powinny być stosowane u chorych } \\
\text { z przewlekłą pokrzywką regularnie czy doraźnie? }\end{array}$} \\
\hline
\end{tabular}

\begin{tabular}{|l|l|l|}
\hline Sugerujemy regularne stosowanie leków & $\uparrow$ & Konsensus \\
\hline
\end{tabular} \begin{tabular}{ll|l} 
przeciwhistaminowych drugiej generacji & $>90 \%$
\end{tabular} blokujących receptory $\mathrm{H}_{1}$ w leczeniu chorych z przewlekłą pokrzywką (w oparciu o dowody i konsensus)

Czy w tym samym czasie należy stosować różne leki przeciwhistaminowe drugiej generacji blokujące receptory $\mathrm{H}_{1}$ ?

\begin{tabular}{|l|l|l|}
\hline Zalecamy, aby nie stosować różnych leków & $\downarrow \downarrow$ & Konsensus
\end{tabular} \begin{tabular}{l|l} 
przeciwhistaminowych drugiej generacji & $>90 \%$
\end{tabular} blokujących receptory $\mathrm{H}_{1}$ w tym samym czasie (w oparciu o konsensus)
Przeprowadzono badania wykazujące u poszczególnych chorych korzyści ze zwiększenia dawki leków przeciwhistaminowych drugiej generacji blokujących receptory $\mathrm{H}_{1}$ [103-105], potwierdzając wyniki wcześniejszych badań, które doprowadziły do tych samych wniosków w odniesieniu do leków przeciwhistaminowych pierwszej generacji $[106,107]$. Zweryfikowano to w badaniach, w których stosowano bilastynę, cetyryzynę, desloratadynę, ebastynę, feksofenadynę, lewocetyryzynę i rupatadynę w dawkach nawet 4-krotnie przewyższających dawki standardowe [103, 104, 108-111].

Podsumowując - wyniki przytoczonych badań sugerują, że większość chorych z pokrzywką nieodpowiadających na standardowe dawki odniesie korzyści ze zwiększenia dawki leków przeciwhistaminowych. Nowoczesne leki przeciwhistaminowe drugiej generacji blokujące receptory $\mathrm{H}_{1}$ w zarejestrowanych dawkach stanowią pierwszą linię leczenia chorych z pokrzywką, a w zwiększonych dawkach podawane są w drugiej linii leczenia (ryc. 2).

\section{u pacjentów z pokrzywką (leczenie drugiej linii)? \\ Sugerujemy 4-krotne zwiększenie dawki leku przeciwhistaminowego drugiej gene- racji blokującego receptor $\mathrm{H}_{1}$ u pacjentów z przewlekłą pokrzywką nieodpowiada- jącą na pojedynczą dawkę leku przeciw- histaminowego drugiej generacji bloku- jącego receptor $\mathrm{H}_{1}$ (w oparciu o dowody naukowe i konsensus)}

Czy 4-krotne zwiększenie dawki nowoczesnego leku przeciwhistaminowego drugiej generacji blokującego receptor $\mathrm{H}_{1}$ jest przydatne i może być preferowanym sposobem postępowania w porównaniu z innymi metodami

Czy w przypadku braku poprawy należy stosować większe niż 4-krotne dawki leku przeciwhistaminowego drugiej generacji blokującego receptor $\mathrm{H}_{1}$ ?

\begin{tabular}{|l|c|c|}
\hline Zalecamy, aby nie zwiększać więcej & $\downarrow \downarrow$ & Konsensus \\
niż 4-krotnie standardowej dawki leku & & $>90 \%$ \\
przeciwhistaminowego drugiej generacji & & \\
blokującego receptor $\mathrm{H}_{1}$ u pacjentów & & \\
$\begin{array}{l}\text { z przewlekłą pokrzywką (w oparciu } \\
\text { o konsensus) }\end{array}$ & & \\
\hline
\end{tabular}




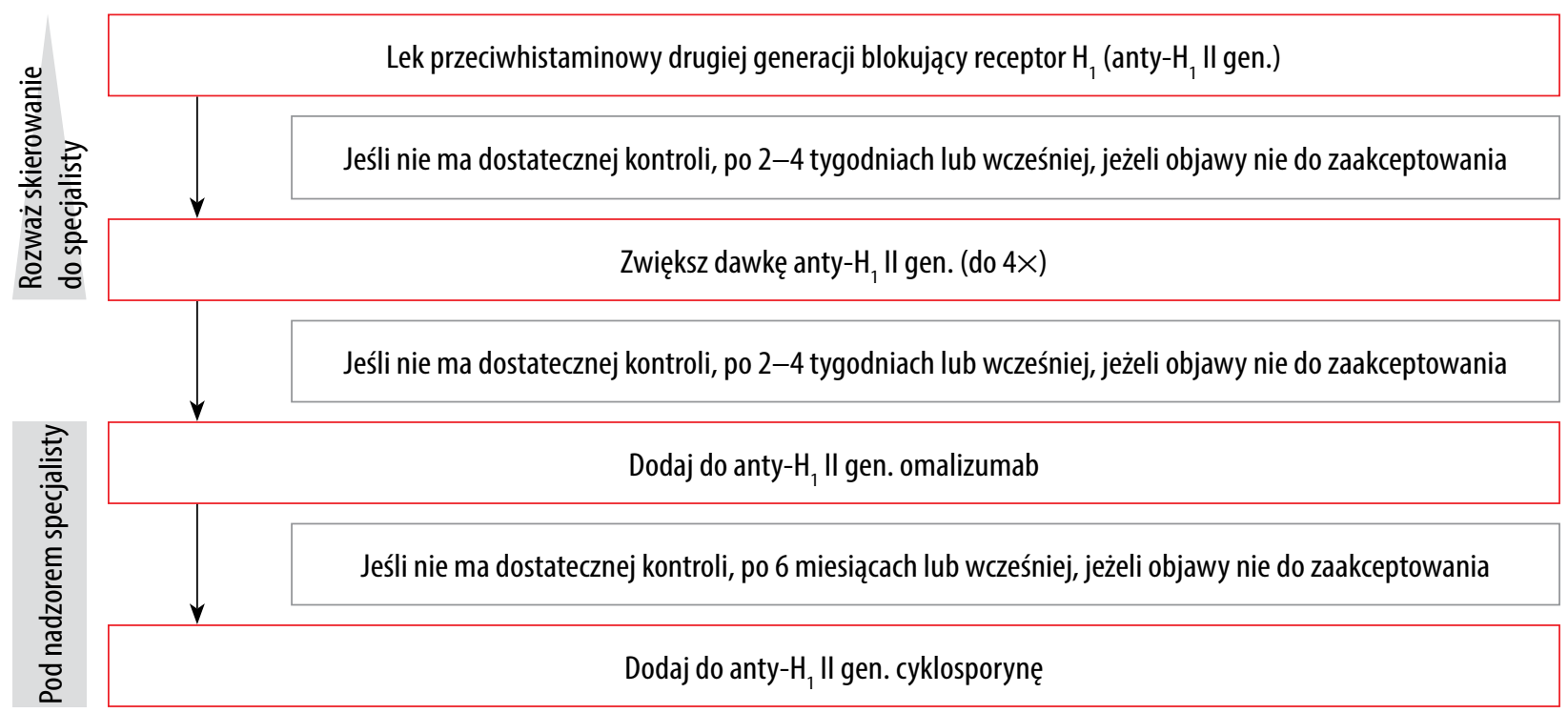

RYCINA 2. Zalecany algorytm leczenia pokrzywki

Algorytm leczenia pokrzywki przewlekłej. Algorytm ten poddano głosowaniu po zakończeniu głosowania wszystkich oddzielnych pytań GRADE, uwzględnionych w obecnych wytycznych. Zdecydowano, że próbę leczenia omalizumabem należy podjąć przed zastosowaniem cyklosporyny A, ponieważ nie jest ona zarejestrowana do leczenia chorych z pokrzywką i wykazuje gorszy profil działań niepożądanych. Ponadto w przypadku ciężkiego zaostrzenia można rozważyć podanie krótkiego kursu glikokortykosteroidów. Dostępne są inne opcje terapeutyczne, patrz tabela 9 . Konsensus $>90 \%$.

Pierwsza linia = dowody naukowe wysokiej jakości: niskie koszty i dostępność na całym świecie (np. nowoczesne leki przeciwhistaminowe drugiej generacji są dostępne także w krajach rozwijających się i są tam znacznie tańsze niż starsze leki przeciwhistaminowe wykazujące działanie sedatywne), podawane są w jednej dawce dobowej z uwagi na dużo dłuższy okres półtrwania, wykazują bardzo dobry profil bezpieczeństwa i dobrą skuteczność.

Druga linia = dowody naukowe wysokiej jakości: niskie koszty, dobry profil bezpieczeństwa, dobra skuteczność.

W trzeciej linii jako lek dodany do leku przeciwhistaminowego.

Omalizumab = dowody naukowe wysokiej jakości: wysokie koszty, bardzo dobry profil bezpieczeństwa, bardzo dobra skuteczność.

W czwartej linii jako lek dodany.

Cyklosporyna $\mathrm{A}=$ dowody naukowe wysokiej jakości: koszty średnie do wysokich, umiarkowany profil bezpieczeństwa, dobra skuteczność.

Krótkotrwałe stosowanie glikokortykosteroidów = dowody naukowe niskiej jakości: niskie koszty, dostępność na całym świecie, dobry profil bezpieczeństwa (tylko w przypadku krótkotrwałego leczenia), dobra skuteczność w trakcie leczenia, ale nieodpowiednie w długotrwałej terapii.

\subsection{KOLEJNE OPCJE TERAPEUTYCZNE U PACJENTÓW Z BRAKIEM SKUTECZNOŚCI LECZENIA PRZECIWHISTAMINOWEGO}

Stwierdzono, że omalizumab (anty-IgE) jest bardzo skuteczny i bezpieczny w leczeniu chorych z CSU [112117]. Wykazano też skuteczność omalizumabu u chorych z CIndU [118, 119], w tym z pokrzywką cholinergiczną [120], pokrzywką z zimna $[68,121]$, pokrzywką słoneczną [122], pokrzywką z ciepła [123], objawowym dermografizmem [67, 124], a także pokrzywką opóźnioną $\mathrm{z}$ ucisku [125]. U chorych z CSU omalizumab zapobiega występowaniu obrzęku naczynioruchowego [126], wyraźnie poprawia jakość życia $[9,127]$, jest odpowiedni do długotrwałego leczenia [128] oraz wykazuje skuteczność w leczeniu nawrotów choroby po zakończeniu leczenia $[128,129]$. Omalizumab jest skuteczny u chorych z CU, w dawkach 150-300 mg co miesiąc. Dawkowanie jest niezależne od całkowitego stężenia IgE w surowicy [112]. Zalecana dawka u chorych z CSU wynosi $300 \mathrm{mg}$ co 4 tygodnie. Zarejestrowane dawki i czas trwania leczenia różnią się w poszczególnych krajach.

\begin{tabular}{|c|c|c|}
\hline $\begin{array}{l}\text { Czy omalizumab jest przydatny jako lek } \\
\text { u chorych nieodpowiadających na wyso } \\
\text { przeciwhistaminowych blokujących rec } \\
\text { linia leczenia chorych na pokrzywkę)? }\end{array}$ & & $\begin{array}{l}\text { ków } \\
\text { ecia }\end{array}$ \\
\hline $\begin{array}{l}\text { Zalecamy dodawanie omalizumabu* do } \\
\text { leczenia chorych z CU nieodpowiadających } \\
\text { na wysokie dawki leków przeciwhista- } \\
\text { minowych drugiej generacji blokujących } \\
\text { receptor } \mathrm{H}_{1} \text { (w oparciu o dowody naukowe } \\
\text { i konsensus) } \\
\text { *0becnie zarejestrowany do leczenia } \\
\text { chorych na pokrzywkę. }\end{array}$ & $\uparrow \uparrow$ & $\begin{array}{c}\text { Konsensus } \\
>90 \%\end{array}$ \\
\hline
\end{tabular}

Cyklosporyna A wykazuje także umiarkowane, bezpośrednie działanie na uwalnianie mediatorów przez komórki tuczne [130, 131]. Skuteczność cyklosporyny A w skojarzeniu z nowoczesnym lekiem przeciwhistaminowym drugiej generacji blokującym receptory $\mathrm{H}_{1}$ wykazano w badaniach klinicznych kontrolowanych placebo [132-134] oraz w otwartych badaniach klinicznych [135] u chorych z CSU, nie można jednak zalecać stosowania 
tego leku w standardowym leczeniu z uwagi częstsze występowanie działań niepożądanych [133]. Cyklosporyna A stosowana jest u chorych z pokrzywką poza zarejestrowanymi wskazaniami (off-label) i jest zalecana tylko u chorych z ciężką postacią choroby oporną na wszystkie dawki leków przeciwhistaminowych oraz omalizumab w leczeniu skojarzonym. Cyklosporyna A wykazuje jednak dużo lepszy stosunek korzyści do ryzyka w porównaniu z długotrwałym podawaniem kortykosteroidów.

\begin{tabular}{|l|c|}
\hline \multicolumn{2}{|l|}{$\begin{array}{l}\text { Czy cyklosporyna A jest przydatna jako lek dodany } \\
\text { u chorych nieodpowiadających na duże dawki leków } \\
\text { przeciwhistaminowych blokujących receptor } H_{1} \text { (trzecia linia } \\
\text { leczenia chorych na pokrzywkę)? }\end{array}$} \\
\hline $\begin{array}{l}\text { Sugerujemy dodawanie cyklosporyny A do } \\
\text { leczenia chorych z CU nieodpowiadających } \\
\text { na leki przeciwhistaminowe drugiej gene- }\end{array}$ & $\begin{array}{c}\text { Konsensus } \\
\text { racji blokujące receptory } \mathrm{H}_{1} \text { (w oparciu }\end{array}$ \\
$\begin{array}{l}\text { o dowody naukowe i konsensus) } \\
\text { Komentarz autorów: jak przedstawiono w algorytmie leczenia }\end{array}$ \\
$\begin{array}{l}\text { opartym na konsensusie (ryc. 2), który później poddano głoso- } \\
\text { waniu, zdecydowano, że próbę leczenia omalizumabem należy } \\
\text { podjąć przed zastosowaniem cyklosporyny A, ponieważ nie jest } \\
\text { ona zarejestrowana do leczenia chorych z pokrzywką i wykazuje } \\
\text { gorszy profil działań niepożądanych. }\end{array}$ \\
\hline
\end{tabular}

We wcześniejszych randomizowanych badaniach klinicznych oceniano stosowanie antagonistów receptora leukotrienowego. Badania te są trudne do porównania z uwagi na różne badane populacje, na przykład obejmujące wyłącznie chorych nietolerujących aspiryny albo dodatków do żywności lub wykluczających chorych z dodatnim wynikiem testu z surowicą autologiczną (ASST). Ogólnie poziom dowodów naukowych dotyczących skuteczności antagonistów receptora leukotrienowego u pacjentów z pokrzywką jest niski, jednak najlepszy w przypadku montelukastu.

Czy antagoniści receptora leukotrienowego są przydatni jako leki dodane u chorych nieodpowiadających na wysokie dawki leków przeciwhistaminowych blokujących receptor $\mathrm{H}_{1}$ ?

\begin{tabular}{l|c|c|}
\hline $\begin{array}{l}\text { Nie możemy sformułować zalecenia do- } \\
\text { tyczącego stosowania montelukastu jako }\end{array}$ & 0 & $\begin{array}{c}\text { Konsensus } \\
>90 \%\end{array}$ \\
leku dodanego do leku przeciwhistamino- \\
$\begin{array}{l}\text { wego blokującego receptor } \mathrm{H}_{1} \text { u chorych } \\
\text { z pokrzywką nieodpowiadających na leki } \\
\text { przeciwhistaminowe blokujące receptor } \mathrm{H}_{1}\end{array}$ & & \\
(w oparciu o dowody naukowe i konsensus) & & \\
\hline
\end{tabular}

Obecnie w wielu chorobach alergicznych często i z dużą skutecznością stosuje się miejscowe kortykosteroidy, jednak u chorych z pokrzywką miejscowe kor- tykosteroidy nie są przydatne (z możliwym wyjątkiem dotyczącym ich stosowania na podeszwy stóp w pokrzywce $\mathrm{z}$ ucisku jako alternatywnego leczenia o niewielkim stopniu udowodnionej skuteczności). W przypadku stosowania kortykosteroidów systemowych konieczne jest zastosowanie dawek pomiędzy 20 a $50 \mathrm{mg} /$ dobę dla prednizonu, przy świadomości występowania działań niepożądanych w trakcie długotrwałego stosowania. Istnieją silne zalecenia dotyczące niestosowania długotrwałego kortykosteroidów poza specjalistycznymi klinikami. Należy podkreślić, że w zależności od kraju kortykosteroidy mogą nie być zarejestrowane do leczenia chorych z pokrzywką przewlekłą (np. w Niemczech prednizolon jest zarejestrowany jedynie do leczenia chorych z ostrą pokrzywką). W przypadku ostrej pokrzywki lub ostrego zaostrzenia CSU może być jednak przydatne krótkotrwałe zastosowanie kortykosteroidów obejmujące leczenie maksymalnie przez 10 dni, w celu skrócenia czasu trwania lub zmniejszenia aktywności choroby [136, 137]. Brakuje jednak dobrze zaprojektowanych randomizowanych badań klinicznych.

\section{Czy doustne kortykosteroidy powinny być podawane jako lek dodany w leczeniu chorych z pokrzywką?}

\begin{tabular}{l|c|c|}
\hline $\begin{array}{l}\text { Zalecamy niestosowanie długotrwale } \\
\text { kortykosteroidów systemowych u chorych } \\
\text { z CU (w oparciu o konsensus) }\end{array}$ & $\downarrow \downarrow$ & $\begin{array}{c}\text { Konsensus } \\
>90 \%\end{array}$ \\
\hline $\begin{array}{l}\text { Sugerujemy rozważenie krótkotrwałego } \\
\text { zastosowania systemowych glikokortyko- } \\
\text { steroidów u chorych z ostrym zaostrze- } \\
\text { niem CU (w oparciu o konsensus) }\end{array}$ & $\uparrow$ & $\begin{array}{c}\text { Konsensus } \\
>90 \%\end{array}$ \\
\hline
\end{tabular}

Stosowanie leków przeciwhistaminowych w praktyce klinicznej w dawkach wynoszących do 4-krotności dawki zalecanej przez producenta umożliwi kontrolę objawów klinicznych choroby u znacznej części chorych, jednak u pozostałej części chorych, nieodpowiadających na takie leczenie, konieczne jest zastosowanie alternatywnych terapii. Zaleca się odczekanie 1-4 tygodni przed zmianą na alternatywne leczenie, tak aby umożliwić uzyskanie pełnej skuteczności leków przeciwhistaminowych.

Nasilenie pokrzywki może się zmieniać i w każdym momencie może dojść do spontanicznej remisji, dlatego zaleca się wykonywanie co 3-6 miesiący badań kontrolnych oceniających konieczność kontynuowania alternatywnego leczenia.

$\mathrm{Z}$ wyjątkiem omalizumabu i cyklosporyny A, wykazujących ograniczenia związane z ich wysokim kosztem, wiele alternatywnych metod leczenia, takich jak skojarzenie nowoczesnych leków przeciwhistaminowych drugiej generacji blokujących receptory $\mathrm{H}_{1} \mathrm{z}$ antagonistami receptora leukotrienowego, opiera się na wynikach ba- 
dań klinicznych z dowodami naukowymi niskiej jakości (tab. 9). W oparciu o poziom zalecenia zalecane opcje leczenia trzeciej i czwartej linii są w związku z tym bardzo ograniczone (parz ryc. 2 przedstawiająca algorytm).

Obecnie uważa się, że zalecenie w poprzedniej wersji wytycznych antagonistów $\mathrm{H}_{2}$ i dapsonu opiera się na tak niewielu dowodach, że nie należy umieszczać tej opcji leczenia w algorytmie, niemniej może to być korzystny sposób leczenia z punktu widzenia kosztów, zwłaszcza w krajach z bardziej restrykcyjnymi systemami opieki zdrowotnej. Stosowanie sulfasalazyny, metotreksatu, interferonu, plazmaferezy, fototerapii, dożylnych immunoglobulin (intravenous immunoglobulin - IVIG/IGIV) oraz innych opcji terapeutycznych opiera się na dowodach niskiej jakości lub jedynie na publikacji opisu serii przypadków² (tab. 9). Pomimo braku publikowanych dowodów naukowych, wszystkie wymienione leki mogą wykazywać pewną przydatność u poszczególnych chorych w odpowiedniej sytuacji klinicznej [138].

\section{Czy leki przeciwhistaminowe blokujące receptory $\mathrm{H}_{2}$ są przydatne jako lek dodany u chorych nieodpowiadających na niskie lub wysokie dawki leków przeciwhistaminowych blokujących receptory $\mathrm{H}_{1}$ ?}

\begin{tabular}{|l|c|c|}
\hline $\begin{array}{l}\text { Nie możemy sformułować zalecenia za } \\
\text { lub przeciwko skojarzonemu stosowaniu }\end{array}$ & 0 & $\begin{array}{c}\text { Konsensus } \\
\text { leków przeciwhistaminowych blokujących }\end{array}$ \\
$\begin{array}{l}\text { receptory } \mathrm{H}_{1} \mathrm{i} \mathrm{H}_{2} \mathrm{u} \text { chorych z przewlekłą } \\
\text { pokrzywką (w oparciu o dowody naukowe } \\
\text { i konsensus) }\end{array}$ & & \\
\hline
\end{tabular}

Antagoniści czynnika martwicy nowotworów a (tumour necrosis factor $\alpha$ - TNF- $\alpha$ ) [139] i IVIG/IGIV [140-143], których skuteczność przedstawiono w opisach przypadków, są obecnie zalecane jedynie do stosowania w ośrodkach specjalistycznych jako ostatnia opcja terapeutyczna (tzn. leki anty-TNF-a stosuje się u chorych z pokrzywką opóźnioną z ucisku, a IVIG/IGIV u chorych z CSU) [144, 145].

U chorych z CSU i objawowym dermografizmem do leczenia przeciwhistaminowego można dodać terapię z zastosowaniem UVB (wąskie pasmo UVB, TL01), UVA i PUVA przez 1 do 3 miesięcy [146-148].

Niektóre wcześniej proponowane alternatywne terapie okazały się nieskuteczne w podwójnie zaślepionych, kontrolowanych placebo badaniach klinicznych i w związ$\mathrm{ku} \mathrm{z}$ tym nie należy ich dłużej stosować $\mathrm{z}$ uwagi na niski stopień zaleceń. Dotyczy to kwasu traneksamowego i kromoglikanu sodu u chorych z CSU $[149,150]$, nifedypiny u chorych $\mathrm{z}$ objawowym dermografizmem lub pokrzywką wywołaną [151] oraz kolchicyny i indometacyny u chorych z pokrzywką opóźnioną z ucisku $[152,153]$. Niemniej ich stosowanie w poszczególnych podgrupach chorych może wymagać przeprowadzenia dalszych badań, takich jak ostatnio przeprowadzone badanie przedstawione $\mathrm{w}$ cytowaniu [145], będące badaniem pilotażowym u chorych z podwyższonym stężeniem D-dimerów, w którym wykazano możliwą skuteczność heparyny i kwasu traneksamowego.

\begin{tabular}{|c|c|c|}
\hline \multicolumn{3}{|c|}{$\begin{array}{l}\text { Czy można zalecić jakieś inne opcje terapeutyczne w trzeciej } \\
\text { linii leczenia chorych z pokrzywką? }\end{array}$} \\
\hline $\begin{array}{l}\text { Nie możemy sformułować zalecenia } \\
\text { w odniesieniu do dalszych opcji terapeu- } \\
\text { tycznych (w oparciu o dowody naukowe } \\
\text { i konsensus) }\end{array}$ & 0 & $\begin{array}{c}\text { Konsensus } \\
>90 \%\end{array}$ \\
\hline
\end{tabular}

\subsection{LECZENIE SZCZEGÓLNYCH POPULACJI}

\subsubsection{Dzieci}

Dla wielu klinicystów pierwszym wyborem w leczeniu dzieci z alergiami są leki przeciwhistaminowe pierwszej generacji blokujące receptory $\mathrm{H}_{1}$ wykazujące działanie sedatywne, ponieważ zakładają oni, że ich profil bezpieczeństwa jest lepiej znany niż w przypadku nowoczesnych leków przeciwhistaminowych drugiej generacji blokujących receptory $\mathrm{H}_{1}$, głównie $\mathrm{z}$ uwagi na dłuższe doświadczenie $\mathrm{z}$ tymi lekami. Ponadto $\mathrm{w}$ wielu krajach nowoczesne leki przeciwhistaminowe drugiej generacji blokujące receptory $\mathrm{H}_{1}$ nie zostały zarejestrowane do stosowania u dzieci poniżej 6. miesiąca życia, natomiast zalecenia dotyczące leków przeciwhistaminowych pierwszej generacji blokujących receptory $\mathrm{H}_{1}$ są czasami mniej jasne, ponieważ leki te rejestrowano w czasie, kiedy zalecenia dotyczące dobrej praktyki klinicznej w przemyśle farmaceutycznym nie były jeszcze tak rygorystyczne. W następstwie tego wielu lekarzy wybiera leki przeciwhistaminowe pierwszej generacji blokujące receptory $\mathrm{H}_{1}$, które jak już wspomniano, wykazują gorszy profil bezpieczeństwa w porównaniu z nowoczesnymi lekami przeciwhistaminowymi drugiej generacji blokującymi receptory $\mathrm{H}_{1}$. Panel ekspertów sformułował wyraźne zalecenie odradzające stosowanie leków przeciwhistaminowych pierwszej generacji u niemowląt i dzieci. W związku z tym u dzieci zaleca się takie samo leczenie pierwszej linii, ze zwiększeniem dawki leku (dostosowanym do masy ciała i wieku dziecka), jak u dorosłych. W populacji pediatrycznej należy stosować tylko leki o udowodnionej skuteczności i bezpieczeństwie. Cetyryzyna [155], desloratadyna [156, 157], feksofenadyna [158], lewocetyryzyna [159], rupatadyna [160], bilastyna [161] i loratadyna [155] zostały dobrze przebadane u dzieci, a ich długotrwałe bezpieczeństwo zostało potwierdzone w populacji pediatrycznej. Ponadto wybór nowoczesnych leków przeciwhistaminowych drugiej generacji blokujących receptory $\mathrm{H}_{1} \mathrm{u}$ dzieci zależy od wieku 
dziecka i dostępności, ponieważ nie wszystkie leki dostępne są w postaciach odpowiednich dla dzieci, takich jak syrop czy szybko rozpuszczająca się tabletka. Najniższy wiek, dla którego zarejestrowano dany lek, także różni się pomiędzy poszczególnymi krajami. Wszelkie dalsze decyzje należy opierać na indywidulanej sytuacji chorego i rozważać z dużą ostrożnością, ponieważ na przykład możliwość zwiększenia dawki leku przeciwhistaminowego $\mathrm{i}$ inne opcje terapeutyczne nie zostały dokładnie przebadane u dzieci.

\begin{tabular}{|c|c|c|}
\hline \multicolumn{3}{|c|}{$\begin{array}{l}\text { Czy u dzieci należy stosować ten sam algorytm } \\
\text { terapeutyczny? }\end{array}$} \\
\hline $\begin{array}{l}\text { Sugerujemy stosowanie u dzieci z prze- } \\
\text { wlekłą pokrzywką tego samego algoryt- } \\
\text { mu z zachowaniem ostrożności (w oparciu } \\
\text { o konsensus) }\end{array}$ & $\uparrow$ & $\begin{array}{c}\text { Konsensus } \\
>90 \%\end{array}$ \\
\hline
\end{tabular}

TABELA 8. Obszary dalszych badań u chorych z pokrzywką

- Ogólna epidemiologia u dorosłych i dzieci

- Następstwa socjoekonomiczne

- Identyfikacja czynników aktywujących komórki tuczne lub bazofile

- Identyfikacja nowych markerów histologicznych

- Identyfikacja biomarkerów surowiczych aktywności pokrzywki lub aktywacji komórek tucznych

- Określenie minimalnych istotnych różnic dla narzędzi stosowanych do oceny aktywności choroby lub uzyskania odpowiedzi (np. UAS, CU-Q2oL)

- Wyjaśnienie roli krzepnięcia lub czynników krzepnięcia w CSU

- Opracowanie komercyjnie dostępnych testów in vitro do wykrywania autoprzeciwciał w surowicy skierowanych przeciwko lgE lub FceRI

- Badania nad autoprzeciwciałami skierowanymi przeciwko lgE

- Wyjaśnienie powiązanych chorób psychicznych lub psychosomatycznych oraz ich wpływu na przebieg pokrzywki

- Patomechanizmy w pokrzywce lub obrzęku naczynioruchowym z opornością na leki przeciwhistaminowe

- podwójnie zaślepione badania kliniczne porównujące różne nowoczesne leki przeciwhistaminowe drugiej generacji blokujące receptory $\mathrm{H}_{1}$ stosowane w wyższych dawkach u chorych z CSU i różnymi podtypami pokrzywki

- Wpływ regularnego vs doraźnego stosowania leków przeciwhistaminowych blokujących receptory $\mathrm{H}_{1}$ na czas trwania lub nasilenie pokrzywki

- Profil bezpieczeństwa dostępnych terapii, bezpieczeństwo długookresowe

- Wieloośrodkowe badania nad możliwym wpływem antykoagulantów (doustnych i pochodnych heparyny) na CSU

- Kontrolowane wieloośrodkowe badania nad możliwym wpływem dodanych leków, takich jak leki przeciwhistaminowe blokujące receptory $\mathrm{H}_{2}$, montelukast, sulfony (dapson lub sulfasalazyna), metotreksat, azatiopryna

\subsubsection{Kobiety w ciąży i karmiące piersią}

Te same uwagi ogólne dotyczą kobiet w ciąży i karmiących piersią. Ogólnie u kobiet w ciąży należy unikać stosowania jakiegokolwiek leczenia systemowego, zwłaszcza w pierwszym trymestrze. Z drugiej jednak strony kobiety ciężarne mają prawo do najlepszej możliwej terapii. Nie przeprowadzono systematycznych badań nad bezpieczeństwem leczenia u kobiet w ciąży chorych na pokrzywkę, należy jednak podkreślić, że nie zbadano też możliwego negatywnego wpływu zwiększonego stężenia histaminy w przebiegu pokrzywki na organizm ciężarnej. Odnośnie do leczenia dotychczas nie opublikowano przypadków występowania wad wrodzonych u dzieci kobiet, które w czasie ciąży przyjmowały leki przeciwhistaminowe drugiej generacji. Niemniej dostępne są jedynie dane $\mathrm{z}$ badań $\mathrm{w}$ małych grupach kobiet otrzymujących cetyryzynę [162] oraz jedna duża metaanaliza dotycząca loratadyny [163]. Ponadto z uwagi na fakt, że kilka nowoczesnych leków przeciwhistaminowych drugiej generacji dostępnych jest bez recepty i powszechnie stosowanych przez chorych $z$ alergicznym nieżytem błony śluzowej nosa czy pokrzywką, należy założyć, że wiele kobiet stosuje te leki, zwłaszcza na początku ciąży, jeszcze przed jej potwierdzeniem. Niemniej jednak trzeba pamiętać o konieczności zachowania najwyższych standardów bezpieczeństwa w czasie leczenia kobiet w ciąży, dlatego sugeruje się, aby w przypadku stosowania nowoczesnych leków przeciwhistaminowych drugiej generacji preferować loratadynę, z możliwością ekstrapolacji dotyczących jej danych na desloratadynę oraz cetyryzynę z możliwością ekstrapolacji na lewocetyryzynę. Wszystkie leki przeciwhistaminowe blokujące receptory $\mathrm{H}_{1}$ wydzielane są do mleka matki w małych stężeniach. Zaleca się stosowanie leków przeciwhistaminowych drugiej generacji blokujących receptory $\mathrm{H}_{1}$, ponieważ u niemowląt karmionych piersią może dojść do sedacji wskutek obecności w mleku matki leków przeciwhistaminowych pierwszej generacji blokujących receptory $\mathrm{H}_{1}$.

Zwiększenie dawki nowoczesnych leków przeciwhistaminowych drugiej generacji można starannie rozważyć u ciężarnych, ponieważ nie przeprowadzono badań bezpieczeństwa, a w przypadku loratadyny trzeba pamiętać, że lek ten jest metabolizowany w wątrobie, w przeciwieństwie do jej metabolitu, tj. desloratadyny. Należy unikać leków przeciwhistaminowych pierwszej generacji blokujących receptory $\mathrm{H}_{1}$ [100]. Omalizumab został uznany za bezpieczny u kobiet w ciąży, a dotychczas nie ma doniesień o teratogenności leku [164-166]. Wszystkie dalsze decyzje należy podejmować w oparciu o indywidualne uwarunkowania, z preferowaniem leków o zadowalającym stosunku korzyści do ryzyka dla ciężarnych i noworodków w odniesieniu do teratogenności i embriotoksyczności. Na przykład cyklosporyna, mimo 
TABELA 9. Alternatywne opcje terapeutyczne. Niewiele jest danych dostępnych w piśmiennictwie, jednak doświadczenie kliniczne wskazuje, że mogą być one użyteczne w określonych sytuacjach klinicznych. Poszczególne interwencje wymieniono w kolejności alfabetycznej w zależności od częstości stosowania, a nie z uwagi na skuteczność

\section{Interwencja}

Substancja (klasa)

Wskazanie

Powszechnie stosowane

\begin{tabular}{l|c|c}
\hline Leki przeciwdepresyjne & Doksepina $^{\mathrm{a}}$ & CSU \\
\hline Dieta & Dieta pozbawiona pseudoalergenów & CSU \\
\hline $\begin{array}{l}\text { Leki przeciwhistaminowe blokujące } \\
\text { receptory } \mathrm{H}_{2}\end{array}$ & Ranitydyna & CSU \\
\hline Leki immunosupresyjne & Metotreksat & CSU \pm DPU \\
\hline Antagoniści receptora leukotrienowego & Mykofenolan mofetylu & Autoimmunologiczna CSU \\
\hline Sulfony & Montelukast & CSU, DPU \\
\hline
\end{tabular}

Niezbyt często stosowane

\begin{tabular}{|c|c|c|}
\hline Steroidy anaboliczne & Danazol & Pokrzywka cholinergiczna \\
\hline Antykoagulanty & Warfaryna & CSU \\
\hline Leki przeciwfibrynolityczne & Kwas traneksamowy & CSU z obrzękiem naczynioruchowym \\
\hline \multirow[t]{2}{*}{ Leki immunomodulujące } & IVIG & Autoimmunologiczna CSU \\
\hline & Plazmafereza & Autoimmunologiczna CSU \\
\hline \multirow[t]{2}{*}{ Różne } & Autologiczna krew lub surowica & CSU \\
\hline & Hydroksychlorochina & CSU \\
\hline Fototerapia & Wąskie pasmo UV-B & Dermografizm objawowy \\
\hline Psychoterapia & Medycyna holistyczna & CSU \\
\hline \multicolumn{3}{|l|}{ Rzadko stosowane } \\
\hline Antykoagulanty & Heparyna & CSU \\
\hline \multirow[t]{2}{*}{ Leki immunosupresyjne } & Cyklofosfamid & Autoimmunologiczna CSU \\
\hline & Rytuksymab & Autoimmunologiczna CSU \\
\hline \multirow[t]{7}{*}{ Różne } & Anakinra & DPU \\
\hline & Anty-TNF-a & $\mathrm{CSU} \pm \mathrm{DPU}$ \\
\hline & Kamostat mesylanu & CSU \\
\hline & Kolchicyna & CSU \\
\hline & Miltefozyna & CSU \\
\hline & Mirtazapina & CSU \\
\hline & PUVA & CSU \\
\hline \multicolumn{3}{|l|}{ Bardzo rzadko stosowane } \\
\hline Leki immunosupresyjne & Takrolimus & CSU \\
\hline \multirow[t]{2}{*}{ Różne } & Witamina D & CSU \\
\hline & Interferon $\alpha$ & CSU \\
\hline
\end{tabular}

${ }^{a}$ Wykazuje także właściwości przeciwhistaminowe anty- $\mathrm{H}_{1} \mathrm{i}$ anty- $\mathrm{H}_{2}$.

'Obejmuje także dietę z niską zawartością histaminy, ponieważ dieta pozbawiona pseudoalergenów jest też uboga w histaminę.

Leczenie można rozważyć zwłaszcza w przypadkach, kiedy u chorego współistnieją CSU i DPU.

że nie jest teratogenna, wykazuje w modelach zwierzęcych działanie embriotoksyczne i wiąże się z występowaniem porodów przedwczesnych oraz z niską masą urodzeniową u noworodków ludzkich. Czy korzyści ze stosowania cyklosporyny u chorych z CU są warte podjęcia ryzyka u kobiet ciężarnych, musi zostać określone na podstawie każdego indywidualnego przypadku. Wszystkie decyzje powinny być jednak powtórnie oce- 
niane, zgodnie $\mathrm{z}$ obecnymi zaleceniami opublikowanymi przez urzędy rejestracyjne.

\begin{tabular}{|c|c|c|}
\hline $\begin{array}{l}\text { Czy u kobiet w ciąży i karmiących piersią } \\
\text { ten sam algorytm terapeutyczny? }\end{array}$ & & \\
\hline $\begin{array}{l}\text { Sugerujemy stosowanie tego samego } \\
\text { algorytmu leczenia z zachowaniem } \\
\text { ostrożności zarówno u kobiet w ciąży, jak } \\
\text { i karmiących piersią po dokładnej ocenie } \\
\text { możliwych korzyści i ryzyka. Nie należy } \\
\text { stosować leków przeciwwskazanych u ko- } \\
\text { biet w ciąży (w oparciu o konsensus) }\end{array}$ & $\uparrow$ & $\begin{array}{c}\text { Konsensus } \\
>90 \%\end{array}$ \\
\hline
\end{tabular}

\section{KONIECZNOŚĆ DALSZYCH BADAŃ}

Panel ekspertów i uczestnicy projektu zidentyfikowali kilka obszarów wymagających dalszych badań. Podsumowano je w tabeli 8.

\section{PODZIĘKOWANIA}

Autorzy dziękują lekarzom i specjalistom uczestniczącym w opracowaniu tej zrewidowanej i uaktualnionej wersji wytycznych poprzez aktywne uczestnictwo w demokratycznym procesie głosowania i dyskusji w trakcie 5. Międzynarodowej Konferencji Uzgodnieniowej nt. Pokrzywki ( $5^{\text {th }}$ International Consensus Meeting on Urticaria) w 2016 roku. Wyrażają też podziękowanie wszystkich krajowym towarzystwom naukowym za finansowanie swoich delegatów, a następującym towarzystwom naukowym składają szczególne podziękowania za wkład finansowy w zakresie kosztów spotkania oraz prac metodologicznych: EAACI, EADV, EDF, GA²LEN, WAO. Dziękują także Tamarze Dorr za znaczny udział i pomoc w przygotowaniu manuskryptu oraz GA $^{2}$ LEN-UCARENetwork (www.ga2len-ucare.com) za wsparcie naukowe.

Towarzystwa naukowe akceptujące wytyczne: AAAAI (American Academy of Allergy, Asthma \& Immunology) (przyjmujący z komentarzami); AAD (American Academy of Dermatology); AAIITO (Italian Association of Hospital and Territorial Allergists and Immunologists); ACAAI (American College of Allergy, Asthma and Immunology); AEDV (Spanish Academy of Dermatology and Venereology); APAAACI (Asia Pacific Association of Allergy, Asthma and Clinical Immunology); ASBAI (Brazilian Association of Allergy and Immunopathology); ASCIA (Australasian Society of Clinical Immunology and Allergy); BAD (British Association of Dermatologists); BSACI (British Society for Allergy and Clinical Immunology); CDA (Chinese Dermatologist Association); CMICA (Mexican College of Clinical Immunology and Allergy); CSACI (Canadian Society of Allergy and Clinical Immunology); DDG (German Socie- ty of Dermatology); DDS (Danish Dermatological Society); DGAKI (German Society of Allergology and Clinical Immunology); DSA (Danish Society for Allergology); DST (Dermatological Society of Thailand); EAACI (European Academy of Allergology and Clinical Immunology); EDF (European Dermatology Forum); EMBRN (European Mast Cell and Basophil Research Network); ESCD (European Society of Contact Dermatitis); GA ${ }^{2} \mathrm{LEN}$ (Global Allergy and Asthma European Network); IAACI (Israel Association of Allergy and Clinical Immunology); IADVL (Indian Association of Dermatologists, Venereologists and Leprologists); JDA (Japanese Dermatological Association); NVvA (Dutch Society of Allergology) (the official delegate agreed with the guideline but at time of publication the official letter of endorsement was not received. If received later an update will be published on the GA²LEN website.); MSAI (Malaysian Society of Allergy and Immunology); ÖGDV (Austrian Society for Dermatology); PSA (Polish Society of Allergology); RAACI (Russian Association of Allergology and Clinical Immunology); SBD (Brazilian Society of Dermatology); SFD (French Society of Dermatology); SGAI (Swiss Society for Allergology and Immunology); SGDV (Swiss Society for Dermatology and Venereology); SIAAIC (Italian Society of Allergology, Asthma and Clinical Immunology); SIDeMaST (Italian Society of Medical, Surgical and Aesthetic Dermatology and Sexual Transmitted Diseases); SPDV (Portuguese Society of Dermatology and Venereology); TSD (Turkish Society of Dermatology); UNBB (Urticaria Network BerlinBrandenburg); UNEV (Urticaria Network); WAO (World Allergy Organization).

\section{KONFLIKT INTERESÓW}

Dostępna jest jedynie deklaracja konfliktu interesów pierwszego autora. Prosimy zapoznać się z tabelą w publikacji opisującej metodologię, gdzie przedstawiono w szczegółach deklaracje konfliktu interesów wszystkich autorów.

\section{ORCID}

T. Zuberbier (D) http://orcid.org/0000-0002-1466-8875 R. Asero (D) http://orcid.org/0000-0002-8277-1700 J. A. Bernstein (D) http://orcid.org/0000-0002-3476-1196 Z. Brzoza (D) http://orcid.org/0000-0002-1230-7013 M. Hide (D) http://orcid.org/0000-0001-6183-6467 D. Larenas-Linnemann (D) http://orcid.org/0000-00025713-5331

\section{PIŚMIENNICTWO}

1. Zuberbier T, Asero R, Bindslev-Jensen C, et al. EAACI/GA(2)LEN/ EDF/WAO guideline: definition, classification and diagnosis of urticaria. Allergy 2009; 64: 1417-26. 
2. Zuberbier T, Asero R, Bindslev-Jensen C, et al. EAACI/GA(2)LEN/ EDF/WAO guideline: management of urticaria. Allergy 2009; 64: 1427-43.

3. Zuberbier T, Aberer W, Asero R, et al. The EAACI/GA(2) LEN/ EDF/WAO Guideline for the definition, classification, diagnosis, and management of urticaria: the 2013 revision and update. Allergy 2014; 69: 868-87.

4. Zuberbier T, Aberer W, Asero R, et al. Methods report on the development of the 2013 revision and update of the EAACI/GA2 LEN/EDF/WAO guideline for the definition, classification, diagnosis, and management of urticaria. Allergy 2014; 69: e1-29.

5. Dressler C, Rosumeck S, Werner RN, et al. Executive summary: methods and evidence report for the evidence- and consensus-based (S3) Guideline for the definition, classification, diagnosis, and management of urticaria - revision and update 2017. Allergy 2018; 73: 1145-6.

6. AGREE Next Steps Consortium. The AGREE II Instrument; 2009. http://www.agreetrust.org/. Dostępne 12 stycznia 2015.

7. Higgins JPT, Green S, Cochrane C. Cochrane handbook for systematic reviews of interventions; 2011. http://www.cochrane-handbook.org/

8. Guyatt GH, Oxman AD, Kunz R, et al. GRADE guidelines: 2. Framing the question and deciding on important outcomes. J Clin Epidemiol 2011; 64: 395-400.

9. Finlay AY, Kaplan AP, Beck LA, et al. Omalizumab substantially improves dermatology-related quality of life in patients with chronic spontaneous urticaria. J Eur Acad Dermatol Venereol 2017; 31: 1715-21.

10. Atkins D, Best D, Briss PA, et al. Grading quality of evidence and strength of recommendations. BMJ 2004; 328: 1490.

11. GRADEpro GDT: GRADEpro Guideline Development Tool. McMaster University (developed by Evidence Prime, Inc.) 2015.

12. Jones J, Hunter D. Consensus methods for medical and health services research. BMJ 1995; 311: 376-80.

13. Haas N, Schadendorf D, Henz BM. Differential endothelial adhesion molecule expression in early and late whealing reactions. Int Arch Allergy Immunol 1998; 115: 210-4.

14. Peteiro C, Toribio J. Incidence of leukocytoclastic vasculitis in chronic idiopathic urticaria. Study of 100 cases. Am J Dermatopathol 1989; 11: 528-33.

15. Ito Y, Satoh T, Takayama K, et al. Basophil recruitment and activation in inflammatory skin diseases. Allergy 2011; 66: 1107-13.

16. Kay AB, Clark P, Maurer M, Ying S. Elevations in T-helper-2-initiating cytokines (interleukin-33, interleukin-25 and thymic stromal lymphopoietin) in lesional skin from chronic spontaneous ('idiopathic') urticaria. Br J Dermatol 2015; 172: 1294-302.

17. Kay AB, Ying S, Ardelean E, et al. Calcitonin gene-related peptide and vascular endothelial growth factor are expressed in lesional but not uninvolved skin in chronic spontaneous urticaria. Clin Exp Allergy 2014; 44: 1053-60.

18. Zuberbier T, Schadendorf D, Haas N, et al. Enhanced P-selectin expression in chronic and dermographic urticaria. Int Arch Allergy Immunol 1997; 114: 86-9.

19. Kay AB, Ying S, Ardelean E, et al. Elevations in vascular markers and eosinophils in chronic spontaneous urticarial weals with low-level persistence in uninvolved skin. Br J Dermatol 2014; 171: 505-11.

20. Greaves MW. Chronic urticaria. N Engl J Med 1995; 332: 1767-72.

21. Kaplan AP. Clinical practice. Chronic urticaria and angioedema. N Engl J Med 2002; 346: 175-9.
22. Hermes B, Prochazka AK, Haas N, et al. Upregulation of TNF-alpha and IL-3 expression in lesional and uninvolved skin in different types of urticaria. J Allergy Clin Immunol 1999; 103: 307-14.

23. Maurer M, Weller K, Bindslev-Jensen C, et al. Unmet clinical needs in chronic spontaneous urticaria. A GA(2)LEN task force report. Allergy 2011; 66: 317-30.

24. Baiardini I, Braido F, Bindslev-Jensen C, et al. Recommendations for assessing patient-reported outcomes and health-related quality of life in patients with urticaria: a GA(2) LEN taskforce position paper. Allergy 2011; 66: 840-4.

25. Maurer M, Staubach P, Raap U, et al. H1-antihistamine-refractory chronic spontaneous urticaria: it's worse than we thought - first results of the multicenter real-life AWARE study. Clin Exp Allergy 2017; 47: 684-92.

26. Maurer M, Staubach P, Raap U, et al. ATTENTUS, a German online survey of patients with chronic urticaria highlighting the burden of disease, unmet needs and real-life clinical practice. $\mathrm{Br}$ J Dermatol 2016; 174: 892-4.

27. Maurer M, Abuzakouk M, Berard F, et al. The burden of chronic spontaneous urticaria is substantial: real-world evidence from ASSURE-CSU. Allergy 2017; 72: 2005-16.

28. O'Donnell BF, Lawlor F, Simpson J, et al. The impact of chronic urticaria on the quality of life. Br J Dermatol 1997; 136: 197-201.

29. Baiardini I, Giardini A, Pasquali M, et al. Quality of life and patients' satisfaction in chronic urticaria and respiratory allergy. Allergy 2003; 58: 621-3.

30. Parisi CA, Ritchie C, Petriz N, et al. Direct medical costs of chronic urticaria in a private health organization of Buenos Aires, Argentina. Value Health Reg Issues 2016; 11: 57-9.

31. Broder MS, Raimundo K, Antonova E, Chang E. Resource use and costs in an insured population of patients with chronic idiopathic/ spontaneous urticaria. Am J Clin Dermatol 2015; 16: 313-21.

32. Graham J, McBride D, Stull D, et al. Cost utility of omalizumab compared with standard of care for the treatment of chronic spontaneous urticaria. Pharmacoeconomics 2016; 34: 815-27.

33. Zuberbier T, Maurer M. Urticaria: current opinions about etiology, diagnosis and therapy. Acta Derm Venereol 2007; 87: 196-205.

34. Kolkhir P, Church MK, Weller K, et al. Autoimmune chronic spontaneous urticaria: what we know and what we do not know. J Allergy Clin Immunol 2017; 139: 1772-81.

35. Asero R, Tedeschi A, Marzano AV, Cugno M. Chronic urticaria: a focus on pathogenesis. F1000Res 2017; 6:1095.

36. Kolkhir P, Balakirski G, Merk HF, et al. Chronic spontaneous urticaria and internal parasites - a systematic review. Allergy 2016; 71: 308-22.

37. Imbalzano E, Casciaro M, Quartuccio S, et al. Association between urticaria and virus infections: a systematic review. Allergy Asthma Proc 2016; 37: 18-22.

38. Minciullo PL, Cascio A, Barberi G, Gangemi S. Urticaria and bacterial infections. Allergy Asthma Proc 2014; 35: 295-302.

39. Foti C, Nettis E, Cassano N, et al. Acute allergic reactions to Anisakis simplex after ingestion of anchovies. Acta Derm Venereol 2002; 82: 121-3.

40. Ventura MT, Napolitano S, Menga R, et al. Anisakis simplex hypersensitivity is associated with chronic urticaria in endemic areas. Int Arch Allergy Immunol 2013; 160: 297-300.

41. Dionigi PC, Menezes MC, Forte WC. A prospective ten-year follow-up of patients with chronic urticaria. Allergol Immunopathol (Madr) 2016; 44: 286-91. 
42. Shabrawy RM, Gharib K. Helicobacter pylori Infection as a risk factor in patients suffering from food allergy and urticaria. Egypt J Immunol 2016; 23: 67-75.

43. Curth HM, Dinter J, Nigemeier K, et al. Effects of Helicobacter pylori eradication in chronic spontaneous urticaria: results from a retrospective cohort study. Am J Clin Dermatol 2015; 16: 553-8.

44. Rasooly MM, Moye NA, Kirshenbaum AS. Helicobacter pylori: a significant and treatable cause of chronic urticaria and angioedema. Nurse Pract 2015; 40: 1-6.

45. Chen YJ, Wu CY, Shen JL, et al. Cancer risk in patients with chronic urticaria: a population-based cohort study. Arch Dermatol 2012; 148: 103-8.

46. Konstantinou GN, Asero R, Maurer M, et al. EAACI/GA(2)LEN task force consensus report: the autologous serum skin test in urticaria. Allergy 2009; 64: 1256-68.

47. Konstantinou GN, Asero R, Ferrer M, et al. EAACI taskforce position paper: evidence for autoimmune urticaria and proposal for defining diagnostic criteria. Allergy 2013; 68: 27-36.

48. Curto-Barredo L, Yelamos J, Gimeno R, et al. Basophil activation test identifies the patients with chronic spontaneous urticaria suffering the most active disease. Immun Inflamm Dis 2016; 4: 441-5.

49. Netchiporouk E, Moreau L, Rahme E, et al. Positive CD63 basophil activation tests are common in children with chronic spontaneous urticaria and linked to high disease activity. Int Arch Allergy Immunol 2016; 171: 81-8.

50. Kim Z, Choi BS, Kim JK, Won DI. Basophil markers for identification and activation in the indirect basophil activation test by flow cytometry for diagnosis of autoimmune urticaria. Ann Lab Med 2016; 36: 28-35.

51. Iqbal K, Bhargava K, Skov PS, et al. A positive serum basophil histamine release assay is a marker for ciclosporin-responsiveness in patients with chronic spontaneous urticaria. Clin Transl Allergy 2012; 2: 19.

52. Gericke J, Metz M, Ohanyan T, et al. Serum autoreactivity predicts time to response to omalizumab therapy in chronic spontaneous urticaria. J Allergy Clin Immunol 2017; 139: 1059-61.

53. Grattan CEH, Dawn G, Gibbs S, Francis DM. Blood basophil numbers in chronic ordinary urticaria and healthy controls: diurnal variation, influence of loratadine and prednisolone and relationship to disease activity. Clin Exp Allergy 2003; 33: 337-41.

54. Eckman JA, Hamilton RG, Gober LM, et al. Basophil phenotypes in chronic idiopathic urticaria in relation to disease activity and autoantibodies. J Invest Dermatol 2008; 128: 1956-63.

55. Saini SS, Omachi TA, Trzaskoma B, et al. Effect of omalizumab on blood basophil counts in patients with chronic idiopathic/spontaneous urticaria. J Invest Dermatol 2017; 137: 958-61.

56. Kolkhir P, Andre F, Church MK, et al. Potential blood biomarkers in chronic spontaneous urticaria. Clin Exp Allergy 2017; 47: 19-36.

57. Asero R, Marzano AV, Ferrucci S, Cugno M. D-dimer plasma levels parallel the clinical response to omalizumab in patients with severe chronic spontaneous urticaria. Int Arch Allergy Immunol 2017; 172: 40-4.

58. Mlynek A, Zalewska-Janowska A, Martus P, et al. How to assess disease activity in patients with chronic urticaria? Allergy 2008; 63: 777-80

59. Hawro T, Ohanyan T, Schoepke N, et al. Comparison and interpretability of the available urticarial activity scores. Allergy 2017; 73: $251-5$.
60. Weller KG, Magerl M, Tohme N, et al. Development, validation and initial results of the angioedema activity score. Allergy 2013; 68: 1185-92.

61. Ohanyan T, Schoepke N, Bolukbasi B, et al. Responsiveness and minimal important difference of the urticaria control test. J Allergy Clin Immunol 2017; 140: 1710-3.

62. Weller K, Groffik A, Church MK, et al. Development and validation of the Urticaria Control Test: a patient-reported outcome instrument for assessing urticaria control. J Allergy Clin Immunol 2014; 133: 1365-72.

63. Martinez-Escala ME, Curto-Barredo L, Carnero L, et al. Temperature thresholds in assessment of the clinical course of acquired cold contact urticaria: a prospective observational one-year study. Acta Derm Venereol 2015; 95: 278-82.

64. Abajian M, Curto-Barredo L, Krause K, et al. Rupatadine $20 \mathrm{mg}$ and $40 \mathrm{mg}$ are effective in reducing the symptoms of chronic cold urticaria. Acta Derm Venereol 2016; 96: 56-9.

65. Mlynek A, Magerl M, Siebenhaar F, et al. Results and relevance of critical temperature threshold testing in patients with acquired cold urticaria. Br J Dermatol 2010; 162: 198-200.

66. Koch K, Weller K, Werner A, et al. Antihistamine updosing reduces disease activity in patients with difficult-to-treat cholinergic urticaria. J Allergy Clin Immunol 2016; 138: 1483-5.

67. Maurer M, Schutz A, Weller K, et al. Omalizumab is effective in symptomatic dermographism - results of a randomized placebo-controlled trial. J Allergy Clin Immunol 2017; 140: 870-3.

68. Metz M, Schutz A, Weller K, et al. Omalizumab is effective in cold urticaria - results of a randomized placebo-controlled trial. J Allergy Clin Immunol 2017; 140: 864-7.

69. Magerl M, Altrichter S, Borzova E, et al. The definition, diagnostic testing, and management of chronic inducible urticarias - the EAACI/GA(2)LEN/EDF/UNEV consensus recommendations 2016 update and revision. Allergy 2016; 71: 780-802.

70. Magerl M, Abajian M, Krause K, et al. An improved Peltier effect-based instrument for critical temperature threshold measurement in cold- and heat-induced urticaria. J Eur Acad Dermatol Venereol 2015; 29: 2043-5.

71. Schoepke N, Abajian M, Church MK, Magerl M. Validation of a simplified provocation instrument for diagnosis and threshold testing of symptomatic dermographism. Clin Exp Dermatol 2015; 40: 399-403.

72. Mlynek A, Vieira dos Santos R, Ardelean E, et al. A novel, simple, validated and reproducible instrument for assessing provocation threshold levels in patients with symptomatic dermographism. Clin Exp Dermatol 2013; 38: 360-6.

73. Altrichter S, Salow J, Ardelean E, et al. Development of a standardized pulse-controlled ergometry test for diagnosing and investigating cholinergic urticaria. J Dermatol Sci 2014; 75: 88-93.

74. Azkur D, Civelek E, Toyran M, et al. Clinical and etiologic evaluation of the children with chronic urticaria. Allergy Asthma Proc 2016; 37: 450-7.

75. Lee SJ, Ha EK, Jee HM, et al. Prevalence and risk factors of urticaria with a focus on chronic urticaria in children. Allergy Asthma Immunol Res 2017; 9: 212-9.

76. Church MK, Weller K, Stock P, Maurer M. Chronic spontaneous urticaria in children: itching for insight. Pediatr Allergy Immunol 2011; 22: 1-8.

77. Maurer M, Church MK, Weller K. Chronic urticaria in children still itching for insight. JAMA Dermatol 2017; 153: 1221-2. 
78. Kuemmerle-Deschner JB, Ozen S, Tyrrell PN, et al. Diagnostic criteria for cryopyrin-associated periodic syndrome (CAPS). Ann Rheum Dis 2017; 76: 942-7.

79. Kowalski ML, Woessner K, Sanak M. Approaches to the diagnosis and management of patients with a history of nonsteroidal antiinflammatory drug-related urticaria and angioedema. J Allergy Clin Immunol 2015; 136: 245-51.

80. Shakouri A, Compalati E, Lang DM, Khan DA. Effectiveness of Helicobacter pylori eradication in chronic urticaria: evidence-based analysis using the grading of recommendations assessment, development, and evaluation system. Curr Opin Allergy Clin Immunol 2010; 10: 362-9.

81. Ishaq S, Nunn L. Helicobacter pylori and gastric cancer: a state of the art review. Gastroenerol Hepatol Bed Bench 2015; 8 (Suppl 1): 6-14.

82. Henz BM, Zuberbier T. Causes of urticaria. In: Urticaria - clinical, diagnostic and therapeutic aspects. Henz BM, Zuberbier T, Grabbe J, Monroe E (eds). Springer, Berlin 1998.

83. Ergon MC, Ilknur T, Yucesoy M, Ozkan S. Candida spp. colonization and serum anticandidal antibody levels in patients with chronic urticaria. Clin Exp Dermatol 2007; 32: 740-3.

84. Zuberbier T, Chantraine-Hess S, Hartmann K, Czarnetzki BM. Pseudoallergen-free diet in the treatment of chronic urticaria a prospective study. Acta Derm Venereol 1995; 75: 484-7.

85. Bruno G, Andreozzi P, Graf U. Exercise-induced urticaria-angioedema syndrome: a role in gastroesophageal reflux. Proceedings of the International Symposium on Urticaria. In: Vena GA, Puddu P (eds.) Editrice CSH, Bari, Milan 1998; 85-9.

86. Varghese R, Rajappa M, Chandrashekar L, et al. Association among stress, hypocortisolism, systemic inflammation, and disease severity in chronic urticaria. Ann Allergy Asthma Immunol 2016; 116: 344-8.

87. Kounis NG, Kounis GN, Soufras GD. Exercise-induced urticaria, cholinergic urticaria, and Kounis syndrome. J Pharmacol Pharmacother 2016; 7: 48-50.

88. Grattan CE, Francis DM, Slater NG, et al. Plasmapheresis for severe, unremitting, chronic urticaria. Lancet 1992; 339: 1078-80.

89. Juhlin L. Recurrent urticaria: clinical investigation of 330 patients. Br J Dermatol 1981; 104: 369-81.

90. Pfrommer C, Bastl R, Vieths S, et al. Characterization of naturally occurring pseudoallergens causing chronic urticaria. J Allergy Clin Immunol 1996; 97: 367.

91. Pigatto PD, Valsecchi RH. Chronic urticaria: a mystery. Allergy 2000; 55: 306-8.

92. Bunselmeyer B, Laubach HJ, Schiller M, et al. Incremental buildup food challenge-a new diagnostic approach to evaluate pseudoallergic reactions in chronic urticaria: a pilot study: stepwise food challenge in chronic urticaria. Clin Exp Allergy 2009; 39: 116-26.

93. Nettis E, Colanardi MC, Ferrannini A, Tursi A. Sodium benzoate-induced repeated episodes of acute urticaria/angiooedema: randomized controlled trial. Br J Dermatol 2004; 151: 898-902.

94. Akoglu G, Atakan N, Cakir B, et al. Effects of low pseudoallergen diet on urticarial activity and leukotriene levels in chronic urticaria. Arch Dermatol Res 2012; 304: 257-62.

95. Wagner N, Dirk D, Peveling-Oberhag A, et al. A Popular myth low-histamine diet improves chronic spontaneous urticaria - fact or fiction? J Eur Acad Dermatol Venereol 2016; 31: 650-5.

96. Beissert S, Stander H, Schwarz T. UVA rush hardening for the treatment of solar urticaria. J Am Acad Dermatol 2000; 42: 1030-2.
97. Grob JJ, Auquier P, Dreyfus I, Ortonne JP. How to prescribe antihistamines for chronic idiopathic urticaria: desloratadine daily vs PRN and quality of life. Allergy 2009; 64: 605-12.

98. Weller K, Ardelean E, Scholz E, et al. Can on-demand non-sedating antihistamines improve urticaria symptoms? A double-blind, randomized, single-dose study. Acta Derm Venereol 2013; 93: 168-74.

99. Vonakis BM, Saini SS. New concepts in chronic urticaria. Curr Opin Immunol 2008; 20: 709-16.

100. Church MK, Maurer M, Simons FE, et al. Risk of first-generation $\mathrm{H}(1)$-antihistamines: a GA(2)LEN position paper. Allergy 2010; 65: 459-66.

101. Bousquet J, Khaltaev N, Cruz AA, et al. Allergic Rhinitis and its Impact on Asthma (ARIA) 2008 update (in collaboration with the World Health Organization, GA(2)LEN and AllerGen). Allergy 2008; 63 (Suppl 86): 8-160.

102. Kubo N, Senda M, Ohsumi Y, et al. Brain histamine H1 receptor occupancy of loratadine measured by positron emission topography: comparison of $\mathrm{H} 1$ receptor occupancy and proportional impairment ratio. Hum Psychopharmacol 2011; 26: 133-9.

103. Kontou-Fili K, Paleologos G, Herakleous M. Suppression of histamine-induced skin reactions by loratadine and cetirizine $\mathrm{diHCl}$. Eur J Clin Pharmacol 1989; 36: 617-9.

104. Zuberbier T, Munzberger C, Haustein U, et al. Double-blind crossover study of high-dose cetirizine in cholinergic urticaria. Dermatology 1996; 193: 324-7.

105. Kontou-Fili KK, Maniakatou G, Demaka P. Therapeutic effect of cetirizine $2 \mathrm{HCl}$ in delayed pressure urticaria. Health Sci Rev 1989; 3: $23-5$.

106. Wanderer AA, Ellis EF. Treatment of cold urticaria with cyproheptadine. J Allergy Clin Immunol 1971; 48: 366-71.

107. Kaplan AP, Gray L, Shaff RE, et al. In vivo studies of mediator release in cold urticaria and cholinergic urticaria. J Allergy Clin Immunol 1975; 55: 394-402.

108. Staevska M, Popov TA, Kralimarkova T, et al. The effectiveness of levocetirizine and desloratadine in up to 4 times conventional doses in difficult-to-treat urticaria. J Allergy Clin Immunol 2010; 125: 676-82.

109. Siebenhaar F, Degener F, Zuberbier T, et al. Highdose desloratadine decreases wheal volume and improves cold provocation thresholds compared with standard-dose treatment in patients with acquired cold urticaria: a randomized, placebo-controlled, crossover study. J Allergy Clin Immunol 2009; 123: 672-9.

110. Gimenez-Arnau A, Izquierdo I, Maurer M. The use of a responder analysis to identify clinically meaningful differences in chronic urticaria patients following placebo-controlled treatment with rupatadine 10 and $20 \mathrm{mg}$. J Eur Acad Dermatol Venereol 2009; 23: $1088-91$.

111. Guillen-Aguinaga S, Jauregui Presa I, Aguinaga-Ontoso E, et al. Updosing nonsedating antihistamines in patients with chronic spontaneous urticaria: a systematic review and metaanalysis. $\mathrm{Br}$ J Dermatol 2016; 175: 1153-65.

112. Saini S, Rosen KE, Hsieh HJ, et al. A randomized, placebo-controlled, dose-ranging study of single-dose omalizumab in patients with $\mathrm{H}$-1-antihistamine-refractory chronic idiopathic urticaria. J Allergy Clin Immunol 2011; 128: 567-U195.

113. Maurer M, Altrichter S, Bieber T, et al. Efficacy and safety of omalizumab in patients with chronic urticaria who exhibit IgE against thyroperoxidase. J Allergy Clin Immunol 2011; 128: 202-9.

114. Saini SS, Bindslev-Jensen C, Maurer M, et al. Efficacy and safety of omalizumab in patients with chronic idiopathic/spontaneous 
urticaria who remain symptomatic on $\mathrm{H} 1$ antihistamines: a randomized, placebo-controlled study. J Invest Dermatol 2015; 135: 67-75.

115. Maurer M, Rosen K, Hsieh HJ, et al. Omalizumab for the treatment of chronic idiopathic or spontaneous urticaria. $\mathrm{N}$ Engl J Med 2013; 368: 924-35.

116. Kaplan A, Ledford D, Ashby M, et al. Omalizumab in patients with symptomatic chronic idiopathic/spontaneous urticaria despite standard combination therapy. J Allergy Clin Immunol 2013; 132: 101-9.

117. Zhao ZT, Ji CM, Yu WJ, et al. Omalizumab for the treatment of chronic spontaneous urticaria: a meta-analysis of randomized clinical trials. J Allergy Clin Immunol 2016; 137: 1742-50.

118. Maurer M, Metz M, Brehler R, et al. Omalizumab treatment in chronic inducible urticaria: a systematic review of published evidence. J Allergy Clin Immunol 2018; 141: 638-49.

119. Metz M, Altrichter S, Ardelean E, et al. Anti-immunoglobulin E treatment of patients with recalcitrant physical urticaria. Int Arch Allergy Immunol 2011; 154: 177-80.

120. Metz M, Bergmann P, Zuberbier T, Maurer M. Successful treatment of cholinergic urticaria with anti-immunoglobulin E therapy. Allergy 2008; 63: 247-9.

121. Boyce JA. Successful treatment of cold-induced urticaria/anaphylaxis with anti-IgE. J Allergy Clin Immunol 2006; 117: 1415-8.

122. Guzelbey O, Ardelean E, Magerl M, et al. Successful treatment of solar urticaria with anti-immunoglobulin E therapy. Allergy 2008; 63: 1563-5.

123. Bullerkotte U, Wieczorek D, Kapp A, Wedi B. Effective treatment of refractory severe heat urticaria with omalizumab. Allergy 2010; 65: 931-2.

124. Krause K, Ardelean E, Kessler B, et al. Antihistamine-resistant urticaria factitia successfully treated with anti-immunoglobulin $\mathrm{E}$ therapy. Allergy 2010; 65: 1494-5.

125. Bindslev-Jensen C, Skov PS. Efficacy of omalizumab in delayed pressure urticaria: a case report. Allergy 2010; 65: 138-9.

126. Staubach P, Metz M, Chapman-Rothe N, et al. Effect of omalizumab on angioedema in $\mathrm{H} 1$-antihistamine-resistant chronic spontaneous urticaria patients: results from X-ACT, a randomized controlled trial. Allergy 2016; 71: 1135-44.

127. Maurer M, Sofen H, Ortiz B, et al. Positive impact of omalizum$\mathrm{ab}$ on angioedema and quality of life in patients with refractory chronic idiopathic/spontaneous urticaria: analyses according to the presence or absence of angioedema. J Eur Acad Dermatol Venereol 2017; 31: 1056-63.

128. Maurer M, Kaplan A, Rosén K, et al. The XTEND-CIU study: long term use of omalizumab in chronic idiopathic urticaria. J Allergy Clin Immunol 2018; 141: 1138-9.

129. Metz M, Ohanyan T, Church MK, Maurer M. Retreatment with omalizumab results in rapid remission in chronic spontaneous and inducible urticaria. JAMA Dermatol 2014; 150: 288-90.

130. Stellato C, de Paulis A, Ciccarelli A, et al. Anti-inflammatory effect of cyclosporin A on human skin mast cells. J Invest Dermatol 1992; 98: 800-4.

131. Harrison CA, Bastan R, Peirce MJ, et al. Role of calcineurin in the regulation of human lung mast cell and basophil function by cyclosporine and FK506. Br J Pharmacol 2007; 150: 509-18.

132. Grattan CE, O’Donnell BF, Francis DM, et al. Randomized doubleblind study of cyclosporin in chronic 'idiopathic' urticaria. Br J Dermatol 2000; 143: 365-72.
133. Vena GA, Cassano N, Colombo D, et al. Cyclosporine in chronic idiopathic urticaria: a double-blind, randomized, placebo-controlled trial. J Am Acad Dermatol 2006; 55: 705-9.

134. Kulthanan K, Chaweekulrat P, Komoltri C, et al. Cyclosporine for chronic spontaneous urticaria: a meta-analysis and systematic review. J Allergy Clin Immunol Pract 2018; 6: 586-99.

135. Doshi DR, Weinberger MM. Experience with cyclosporine in children with chronic idiopathic urticaria. Pediatr Dermatol 2009; 26: 409-13.

136. Zuberbier T, Ifflander J, Semmler C, Henz BM. Acute urticaria: clinical aspects and therapeutic responsiveness. Acta Derm Venereol 1996; 76: 295-7.

137. Asero R, Tedeschi A. Usefulness of a short course of oral prednisone in antihistamine-resistant chronic urticaria: a retrospective analysis. J Investig Allergol Clin Immunol 2010; 20: 386-90.

138. Rutkowski K, Grattan CEH. How to manage chronic urticaria 'beyond' guidelines: a practical algorithm. Clin Exp Allergy 2017; 47: 710-8.

139. Magerl M, Philipp S, Manasterski M, et al. Successful treatment of delayed pressure urticaria with anti-TNF-alpha. J Allergy Clin Immunol 2007; 119: 752-4.

140. O'Donnell BF, Barr RM, Black AK, et al. Intravenous immunoglobulin in autoimmune chronic urticaria. BrJ Dermatol 1998; 138: 101-6.

141. Dawn G, Urcelay M, Ah-Weng A, et al. Effect of high-dose intravenous immunoglobulin in delayed pressure urticaria. Br J Dermatol 2003; 149: 836-40.

142. Pereira C, Tavares B, Carrapatoso I, et al. Low-dose intravenous gammaglobulin in the treatment of severe autoimmune urticaria. Eur Ann Allergy Clin Immunol 2007; 39: 237-42.

143. Mitzel-Kaoukhov H, Staubach P, Muller-Brenne T. Effect of highdose intravenous immunoglobulin treatment in therapy-resistant chronic spontaneous urticaria. Ann Allergy Asthma Immunol 2010; 104: 253-8.

144. Bangsgaard N, Skov L, Zachariae C. Treatment of refractory chronic spontaneous urticaria with adalimumab. Acta Derm Venereol 2017; 97: 524-5.

145. Sand FL, Thomsen SF. TNF-alpha inhibitors for chronic urticaria: experience in 20 patients. J Allergy (Cairo) 2013; 2013:130905.

146. Hannuksela M, Kokkonen EL. Ultraviolet light therapy in chronic urticaria. Acta Derm Venereol 1985; 65: 449-50.

147. Borzova E, Rutherford A, Konstantinou GN, et al. Narrowband ultraviolet B phototherapy is beneficial in antihistamine-resistant symptomatic dermographism: a pilot study. J Am Acad Dermatol 2008; 59: 752-7.

148. Engin B, Ozdemir M, Balevi A, Mevlitoglu I. Treatment of chronic urticaria with narrowband ultraviolet B phototherapy: a randomized controlled trial. Acta Derm Venereol 2008; 88: 247-51.

149. Thormann J, Laurberg G, Zachariae H. Oral sodium cromoglycate in chronic urticaria. Allergy 1980; 35: 139-41.

150. Laurberg G. Tranexamic acid (Cyklokapron) in chronic urticaria: a double-blind study. Acta Derm Venereol 1977; 57: 369-70.

151. Lawlor F, Ormerod AD, Greaves MW. Calcium antagonist in the treatment of symptomatic dermographism. Low-dose and highdose studies with nifedipine. Dermatologica 1988; 177: 287-91.

152. Lawlor F, Black AK, Ward AM, et al. Delayed pressure urticaria, objective evaluation of a variable disease using a dermographometer and assessment of treatment using colchicine. Br J Dermatol 1989; 120: 403-8. 
153. Dover JS, Black AK, Ward AM, Greaves MW. Delayed pressure urticaria. Clinical features, laboratory investigations, and response to therapy of 44 patients. J Am Acad Dermatol 1988; 18: 1289-98.

154. Asero R, Tedeschi A, Cugno M. Heparin and tranexamic Acid therapy may be effective in treatment-resistant chronic urticaria with elevated D-dimer: a pilot study. Int Arch Allergy Immunol 2010; 152: 384-9.

155. Nayak AS, Berger WE, LaForce CF, et al. Randomized, placebo-controlled study of cetirizine and loratadine in children with seasonal allergic rhinitis. Allergy Asthma Proc 2017; 38: 222-30.

156. Gupta S, Khalilieh S, Kantesaria B, Banfield C. Pharmacokinetics of desloratadine in children between 2 and 11 years of age. $\mathrm{Br}$ J Clin Pharmacol 2007; 63: 534-40.

157. Gupta SK, Kantesaria B, Banfield C, Wang Z. Desloratadine dose selection in children aged 6 months to 2 years: comparison of population pharmacokinetics between children and adults. Br J Clin Pharmacol 2007; 64: 174-84.

158. Meltzer EO, Scheinmann P, Rosado Pinto JE, et al. Safety and efficacy of oral fexofenadine in children with seasonal allergic rhinitis - a pooled analysis of three studies. Pediatr Allergy Immunol 2004; 15: 253-60.

159. Pampura AN, Papadopoulos NG, Spicak V, Kurzawa R. Evidence for clinical safety, efficacy, and parent and physician perceptions of levocetirizine for the treatment of children with allergic disease. Int Arch Allergy Immunol 2011; 155: 367-78.

160. Potter P, Mitha E, Barkai L, et al. Rupatadine is effective in the treatment of chronic spontaneous urticaria in children aged 211 years. Pediatr Allergy Immunol 2016; 27: 55-61.

161. Novak Z, Yanez A, Kiss I, et al. Safety and tolerability of bilastine $10 \mathrm{mg}$ administered for 12 weeks in children with allergic diseases. Pediatr Allergy Immunol 2016; 27: 493-8.

162. Weber-Schoendorfer C, Schaefer C. The safety of cetirizine during pregnancy. A prospective observational cohort study. Reprod Toxicol 2008; 26: 19-23.

163. Schwarz EBMM, Nayak S, Koren G. Risk of hypospadias in offspring of women using loratadine during pregnancy: a systematic review and meta-analysis. Drug Saf 2008; 31: 775-88.

164. Namazy J, Cabana MD, Scheuerle AE, et al. The Xolair Pregnancy Registry (EXPECT): the safety of omalizumab use during pregnancy. J Allergy Clin Immunol 2015; 135: 407-12.

165. González-Medina M, Curto-Barredo L, Labrador-Horrillo M, Gimenez-Arnau A. Omalizumab use during pregnancy for chronic spontaneous urticaria (CSU): report of two cases. J Eur Acad Dermatol Venereol 2017; 31: e245-6.

166. Ghazanfar MN, Thomsen SF. Successful and safe treatment of chronic spontaneous urticaria with omalizumab in a woman during two consecutive pregnancies. Case Rep Med 2015; 2015: 368053.

167. Balshem H, Helfand M, Schunemann HJ, et al. GRADE guidelines: 3. Rating the quality of evidence. J Clin Epidemiol 2011; 64: 401-6.

168. Maurer M. Cold urticaria. UpToDate. In: Saini SS, Callen J (eds). Boston, MA: Wolters Kluwer Health; 2014.
Jak cytować artykuł: Zuberbier T, Aberer W, Asero R, et al.; Endorsed by the following societies: AAAAI, AAD, AAIITO, ACAAI, AEDV, APAAACI, ASBAI, ASCIA, BAD, BSACI, CDA, CMICA, CSACI, DDG, DDS, DGAKI, DSA, DST, EAACI, EIAS, EDF, EMBRN, ESCD, GA2LEN, IAACI, IADVL, JDA, NVVA, MSAI, OGDV, PSA, RAACI, SBD, SFD, SGAI, SGDV, SIAAIC, SIDeMaST, SPDV, TSD, UNBB, UNEV and WAO. The EAACI/GA2LEN/EDF/WAO guideline for the definition, classification, diagnosis and management of urticaria. Allergy 2018; 73: 1393-1414. https://doi.org/10.1111/all.13397 